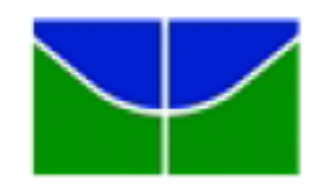

Universidade de Brasília - UnB

Instituto de Psicologia

Departamento de Processos Psicológicos Básicos - PPB

Programa de Pós-Graduação em Ciências do Comportamento

João Paulo Gravina Ribeiro de Castro

Comportamentos e Fisiologia do Estresse de Megaptera novaeangliae ao longo da estação reprodutiva na região do Arquipélago dos Abrolhos (BA - Brasil) 


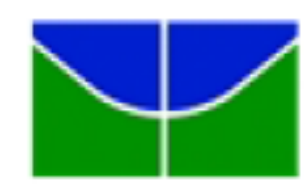

Universidade de Brasília - UnB

Instituto de Psicologia

Departamento de Processos Psicológicos Básicos - PPB

Programa de Pós-Graduação em Ciências do Comportamento

João Paulo Gravina Ribeiro de Castro

Comportamentos e Fisiologia do Estresse de Megaptera novaeangliae ao longo da estação reprodutiva na região do Arquipélago de Abrolhos (BA - Brasil)

Dissertação para conclusão do curso de Mestrado no programa de pós-graduação em Ciências do Comportamento do Departamento de Processos Psicológicos Básicos do Instituto de Psicologia da Universidade de Brasília

Orientador: Prof. Dr. Sergio Leme da Silva Co-Orientação: Prof. Dr. Francisco Dyonísio Cardoso Mendes Brasília, junho 2015 


\section{FICHA CATALOGRÁFICA}

Castro, João Paulo Gravina Ribeiro

Comportamentos e Fisiologia do Estresse de Megaptera novaeangliae ao longo da estação reprodutiva na região do Arquipélago de Abrolhos (BA Brasil). Orientador: Prof. Dr. Sergio Leme da Silva. Brasília, 2015. 46p.

Tese (Mestrado) - Programa de pós-graduação em Ciências do Comportamento/Departamento de Processos Psicológicos Básicos PPB/Instituto de Psicologia - IP/Universidade de Brasília - UnB, 2015.

1. Baleia Jubarte. 2. Comportamento dos Grupos Sociais. 3.Temporada Reprodutiva. 4. Distribuição Geográfica. 5. Estresse.

Nome do autor: João Paulo Gravina Ribeiro de Castro.

Título da dissertação para a conclusão do curso de Mestrado em Ciências do Comportamento: Comportamentos e Fisiologia do Estresse de Megaptera novaeangliae ao longo da estação reprodutiva na região do Arquipélago de Abrolhos (BA - Brasil).

Ano: 2015

A universidade de Brasília tem permissão para fazer cópias desta dissertação e para emprestar ou vender tais cópias somente para fins acadêmicos e científicos. $\mathrm{O}$ autor reserva-se a outros direitos de publicação, nem uma parte desta dissertação pode ser reproduzida sem autorização por escrito do autor.

Nome: João Paulo Gravina Ribeiro de Castro

Endereço: SHIS QL 22 Conjunto 2 casa 4

CEP:71650225

Telefone: (61) 81107025

E-mail: jp.gravina@yahoo.com.br 


\author{
Universidade de Brasília - UnB \\ Instituto de Psicologia \\ Departamento de Processos Psicológicos Básicos - PPB \\ Programa de Pós-Graduação em Ciências do Comportamento
}

\title{
COMISSÃO AVALIADORA
}

Prof. Dr. Sergio Leme Da Silva - IP/UnB

Presidente da Banca

Prof. Dr. Francisco Ernesto Moreno Bernal - FAV/UnB

Membro Titular

Prof. Dra. Tatiana Lemos Bisi - UERJ

Membro Titular

Prof. Dr. Francisco Dyonísio Cardoso Mendes - IP/UnB

Suplente da Banca 
"For those who believe in God, most of the big questions are answered. But for those of us who can't readily accept the God formula, the big answers don't remain stonewritten. We adjust to new conditions and discoveries. We are pliable...

... We are here to unlearn the teachings of the church, state, and our educational system. We are here to drink beer. We are here to kill war. We are here to laugh at the odds and live our lives so well that Death will tremble to take us."

Charles Bukowski 


\section{AGRADECIMENTOS}

Esse trabalho só foi possível devido ao apoio e à colaboração de diversas pessoas: parece-me que na ciência e na vida ninguém faz nada sozinho. Agradeço aos meus pais, Maria das Graças Gravina e Noraldino Ribeiro de Castro, por apoiarem minhas decisões, pelo amor que sempre expressaram em forma de palavras ou de atitudes. Ao meu amigo e orientador Sergio Leme Da Silva que muito tem me ensinado sobre a vida e ciência ao longo destes 10 anos de parceria e de amizade. Ao Francisco Dyonísio Mendes pela coorientação, suas ideias foram fundamentais para que o projeto tomasse forma. Ao Vitor Camargo, estatístico e amigo, pela ajuda e paciência com as análises estatísticas. Ao Renan Smith pela elaboração dos mapas das campanhas. À minha companheira Ana de Luna por trazer dias de sol na minha vida em tempos de vento sul. Ao Antônio de Luna, grande amigo, por revisar o texto desta dissertação.

Aos parceiros do Instituto Baleia Jubarte, Milton Marcondes por abraçar este projeto e por dividir sua experiência e conhecimento a respeito das jubartes e por financiar o custeio das saídas de campo. Aos pesquisadores que tive a sorte de conhecer e de aprender, Adriana Colosio, Aline, Dani Abras, Leonardo Wedekin e Hernani Ramos. Aos estagiários: Cecília Seminara, Jú Nonato, Arnaldo Maruyama, Gustavo, Carolina Marques, João Victor Bertão, Agatha Augusto, Delphine D.M. e Catalina Sánchez. Foi um privilégio conviver temporariamente com essas pessoas, obrigado pela ajuda no campo com as coletas de borrifos, pelas fotos, pela parceria e pelas longas conversas no quintal do alojamento. Não poderia deixar de agradecer à tripulação do barco, ao Bernardo, Mazinho e Kézia por nos conduzir em segurança, pelo bom humor e alegria, não poderia deixar de mencionar a comida maravilhosa.

Meu agradecimento especial aos funcionários do Departamento de Processos Psicológicos básicos Intituto de Psicologia-UnB que estiveram dispostos a ajudar a resolver problemas e esclarecer minhas dúvidas, sempre muito cordiais e pelo apoio financeiro no custeio de algumas viagens e das análises laboratoriais. Ao CNPq pelo apoio financeiro da bolsa que tornou possível minha estadia na Cidade de Caravelas BA. 


\section{SUMÁRIO}

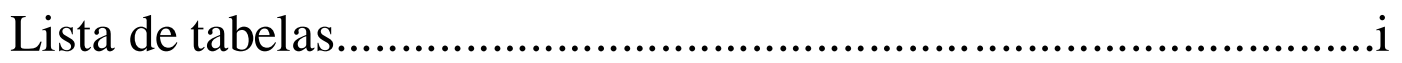

Lista de figuras...........................................................................

Lista de abreviações....................................................................iii

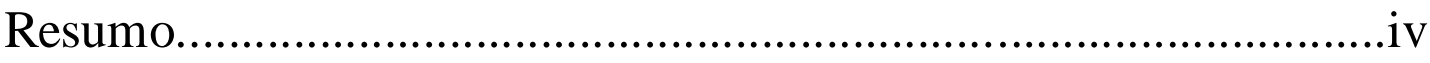

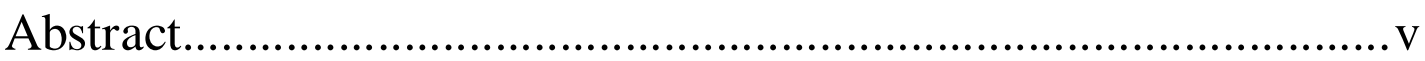

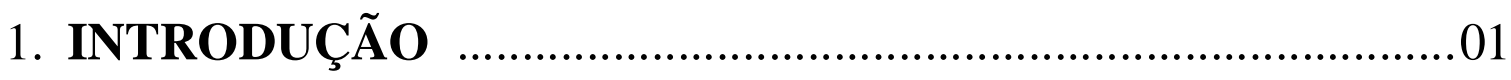

Distribuição e comportamento migratório.............................. 01

Comportamento reprodutivo..............................................02

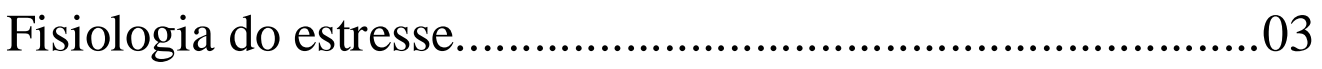

Comportamentos e possíveis interações com estresse.............05

2. OBJETIVOS

Objetivos específicos........................................................06

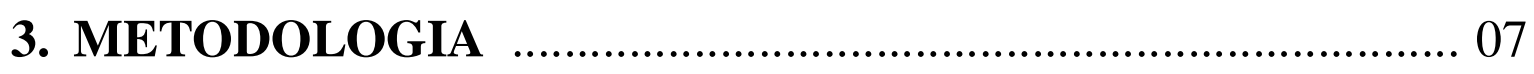

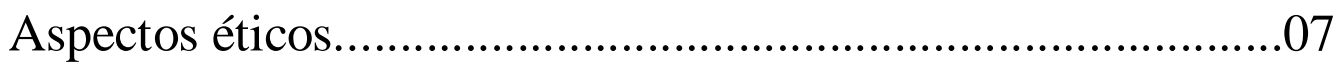

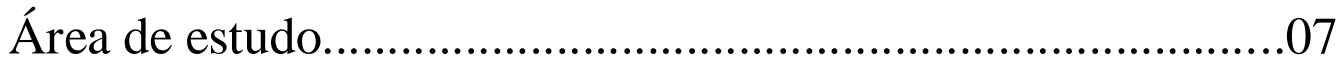

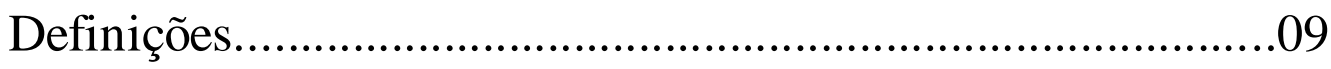

Coleta de dados comportamentais........................................13 
Aferição do cortisol.............................................................14

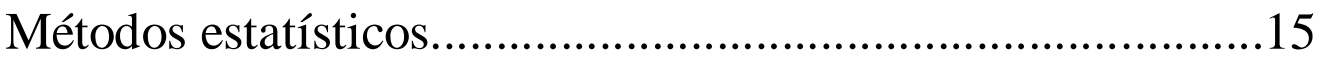

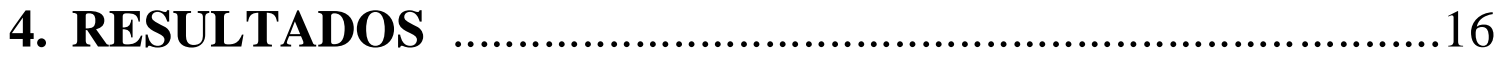

Frequências de avistamentos ao longo da estação reprodutiva e suas distribuiçõoes geográficas.............................................16

Analise das taxas e estados comportamentais por grupo social e ao longo dos meses da estação reprodutiva .......................................21

Níveis do hormônio do estresse cortisol........................................28

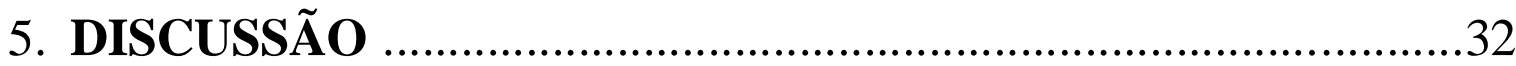

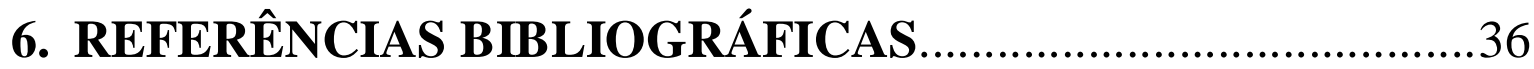

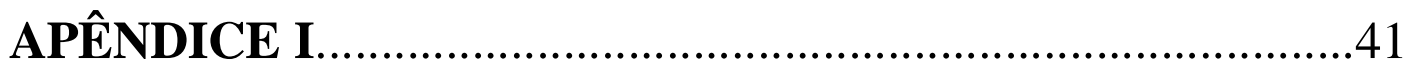

Etograma

APÊNDICE II.

Carta de Aprovação do Comitê de Ética de Uso Animal

APÊNDICE III

Fotos dos Materiais e Métodos

APÊNDICE IV

Fotos dos Comportamentos Superficiais

Fotos de Comportamentos Observados com Drone 


\section{LISTA DE TABELAS}

Tabela 1: Esforço amostral, número de avistamentos e número de baleias adultas avistadas ao longo da temporada reprodutiva de 2014

Tabela 2: Descrições e legendas dos estados e eventos comportamentais que podem ser observados na área de estudo...

Tabela 3: Frequência de avistamentos de filhotes nos grupos sociais por mês ao longo da estação reprodutiva.

Tabela 4: Frequência dos avistamentos de grupos sociais durante os meses da estação reprodutiva.

Tabela 5: Análise MANOVA sobre as taxas comportamentais adulto/hora de estados e eventos observadas em relação aos grupos sociais, aos meses da estação reprodutiva, ao efeito interação grupo $x$ mês da estação.

Tabela 6: Análise ANOVA sobre as taxas comportamentais adulto/hora de estados e eventos observados em relação aos grupos sociais e aos meses da estação reprodutiva.

Tabela 7: Taxas de comportamentos superficiais ou aéreos Agosto e Setembro x Outubro e Novembro

Tabela 8. Taxas de comportamentos superficiais ou aéreos por grupo social. .25

Tabela 9: Taxas de comportamentos superficiais ou aéreos conforme a presença de filhotes..... .26

Tabela 10: Taxas de comportamentos superficiais ou aéreos associada a composições de número de indivíduos em Grupos Competitivos (GC)

Tabela 11: Taxas de comportamentos superficiais ou aéreos nos Grupos Competitivos (GC) conforme a presença de filhotes. .28

Tabela 12: Concentração de cortisol $(\mathrm{Ng} / \mathrm{ml})$ por número de adultos do grupo social .30 


\section{LISTA DE FIGURAS}

Figura 1: Área de amostragem dos comportamentos de Megaptera novaeangliae.................08

Figura 2: Foto da Placa de acrílico para coleta de borrifo......................................................42

Figura 3: Foto do Drone adaptado para coleta de borrifo....................................................42

Figura 4: Frequência de avistamento dos grupos sociais ao longo da estação........................17

Figura 5: Mapas de registros dos grupos sociais por mês da estação reprodutiva..................18

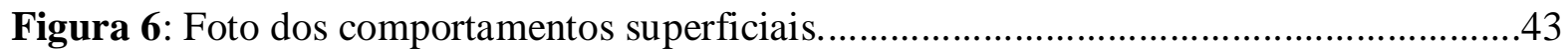

Figura 7: Taxas de comportamentos superficiais ou aéreos por blocos de meses da estação

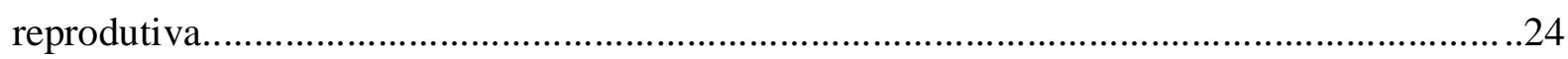

Figura 8: Taxas de comportamentos superficiais ou aéreos por grupo social.......................25

Figura 9: Taxas de comportamentos superficiais ou aéreos conforme a presença de

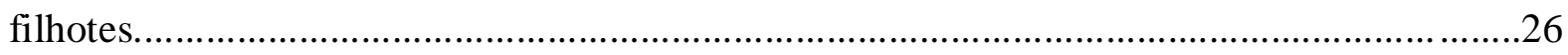

Figura 10: Taxas de comportamentos superficiais o aéreos do Grupo Competitivo (GC)

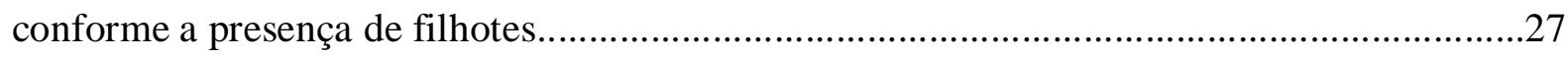

Figura 11: Concentração de cortisol $(\mathrm{Ng} / \mathrm{ml})$ por número de adultos do grupo social...........29

Figura 12: Correlação entre a concentração de cortisol $(\mathrm{Ng} / \mathrm{ml})$ por número de adultos do

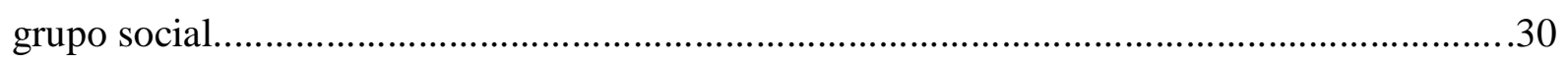

Figura 13: Concentração de cortisol $(\mathrm{Ng} / \mathrm{ml})$ conforme a presença de filhote........................31 


\section{LISTA DE ABREVIATURAS}

DI: Dois indivíduos adultos.

FF: Fêmea e filhote.

FFE: Fêmea filhote e escorte (Macho).

GC: Grupo competitivo, grupo de machos que organizam-se no entorno de uma fêmea com ou sem filhote, caracterizado por comportamentos agressivos. Os machos são denominados escortes.

IS: Indivíduo solitário. 


\section{RESUMO}

As baleias jubarte (Megaptera novaeangliae) organizam-se em grupos sociais temporários ao longo da estação reprodutiva. Investigar aspectos do comportamento em seu contexto social é fundamental para compreender a ecologia comportamental no momento da reprodução e do nascimento, podendo contribuir no estabelecimento de planos de manejo adequados à espécie. O presente trabalho visou estudar os aspectos fisiológicos, comportamentais e de distribuição geográfica dos grupos sociais no contexto da reprodução e do cuidado parental ao longo da temporada reprodutiva, de agosto a novembro, no ano de 2014, na Área de Proteção Ambiental Estadual Ponta da Baleia/ Arquipélago dos Abrolhos. Os resultados apresentados demonstram distribuição geográfica e composição dos grupos sociais diferenciadas entre os meses, sendo que houve uma maior presença de grupos sociais próximos à costa no fim da estação, assim como uma maior presença de fêmeas com filhotes. Em relação aos comportamentos, foi observado maior taxa de estados ativos, eventos ativos e eventos agonísticos para grupos competitivos em relação aos demais grupos sociais; assim como maior taxa de repouso para fêmeas com filhote. Ao avaliar a questão do estresse, grupos com filhote apresentaram níveis de estresse mais elevados do que grupos sem filhote. Diferenças nos níveis de estresse também foram significativas em relação ao número de adultos dos grupos sociais, havendo uma correlação negativa: quanto maior o tamanho do grupo social, menor o estresse. Isso pode estar associado ao estabelecimento de dominância entre machos em um sistema poligínico de dominância em lek.

Palavras chave: 1. Baleia Jubarte. 2. Comportamento dos Grupos Sociais. 3.Temporada Reprodutiva. 4. Distribuição Geográfica. 5. Estresse. 


\begin{abstract}
The hump back whales (Megaptera novaeangliae) are known to aggregate in temporary social groups during the breeding season. Investigation of behavioral aspects within their own social context is basal for understanding the behavioral ecology on breeding and birth context, contributing in the establishment of management plans for the species. This work aimed to study the physiological and behavioral aspects along with the geographical distribution of social groups within the context of reproduction and parental care throughout the humpback whale reproductive season, from August to November, in the year 2014, in the Área de Proteção Ambiental Estadual Ponta da Baleia/ Arquipélago dos Abrolhos. The results show the geographical distribution and the composition of different social groups along the months and there was a greater presence of social groups near the coast at the end of the season, as well as an increased presence of females with cubs. Regarding behaviors, higher rate of active states, active events and agonistic events for competitive groups in relation to other social groups were observed, as well as a higher resting rate for females with a cub. In assessing the issue of stress, groups with cubs showed higher stress levels than those without cubs. Differences in stress levels were also significant regarding the number of adults within social groups, producing a negative correlation: the greater the size of the social group, the smaller the level of stress. This may be linked to the establishment of dominance among males in a polygynous dominance lek system.
\end{abstract}

Key words: 1. Humpback Whale. 2. Social group behavior. 3. Breeding season. 4. Geographical distribution. 5. Stress. 


\section{Introdução}

\section{Distribuição e comportamento migratório}

Megaptera novaeangliae é uma espécie cosmopolita e migratória, podendo ser encontrada em todos os oceanos do planeta (Clapham \& Mead, 1999; Zerbini et al., 2004; Clapham et al., 2009; Rizzo \& Schulte 2009). Sua distribuição muda em determinadas estações do ano entre áreas de alimentação localizadas em altas latitudes, no verão, e áreas de reprodução em baixas latitudes, no inverno (Clapham \& Mead, 1999; Craig et al., 2003; Rizzo \& Schulte 2009; Andriolo \& Zerbini, 2010). Baleiasjubarte são uma espécie comum na costa nordeste brasileira. O Banco dos Abrolhos é uma das principais áreas de reprodução da espécie no Brasil, considerada única devido à alta concentração de fêmeas com filhotes na região (Martins et al., 2001; Morete et al., 2003). Jubarte apresentam certa fidelidade em relação a seus locais de reprodução/ parto e alimentação, assim como rotas migratórias conhecidas (Craig \& Herman, 1997; Stevick et al., 2006; Andriolo \& Zerbini, 2010). Entretanto, indivíduos de uma mesma área de reprodução podem pertencer a diferentes locais de alimentação, assim como indivíduos de uma mesma região de alimentação podem ir se reproduzir em diferentes locais (Stevik et al., 2004). Em baixas latitudes, sabe-se que preferências de uso de habitat estão associadas à organização social onde mães e filhotes preferem águas rasas, provavelmente para evitar predação por tubarões e perseguição dos machos; já grupos competitivos e indivíduos solitários preferem águas mais profundas (Martins et al., 2001; Morete et al., 2007; Lunardi et al., 2008).

Estudos realizados por Rizzo e Schulte (2009) a partir de dados referentes à migração e análise genética sugerem sobreposição de indivíduos de diferentes populações em áreas de reprodução. O comportamento migratório pode estar associado à idade, ao sexo e ao status reprodutivo: fêmeas lactantes com filhotes são as primeiras a migrar para as áreas de reprodução, seguidas por indivíduos imaturos, machos maduros e fêmeas maduras sem filhotes, por fim fêmeas grávidas (Craig et al., 2003; Morete et al., 2007). Fêmeas que não estão completamente maduras não migram para as áreas tropicais de reprodução anualmente, e algumas fêmeas podem se reproduzir ao longo da rota de migração e voltar para sua área de alimentação. Isso pode estar associado à intensa competição entre machos por fêmeas nas áreas de reprodução (Craig \& Herman, 1997). 


\section{Comportamento Reprodutivo}

Durante a estação reprodutiva, machos tendem a gastar mais energia em competições por fêmeas sem filhotes com alto potencial reprodutivo (Craig, 2002). Segundo Clapham (1992), em baixas latitudes há fortes evidências de comportamento competitivo intrassexual, entre indivíduos do mesmo sexo. Grupos competitivos são caracterizados por alta atividade superficial e algumas vezes por altos níveis de agressão entre os participantes, apresentam estrutura definida formada por um animal nuclear (ocupa posição central) com ou sem filhote, cercado por escortes que competem pela proximidade do animal nuclear (Tyack \& Whitehead, 1983; Baker \& Herman, 1984; Clapham et al., 1992).

Em grupos competitivos, machos disputando posição de escorte principal próximo à fêmea, também são vistos saltos e outros comportamentos associados à disputa. Escortes podem acompanhar fêmeas para acasalar com ela ou evitar que outros machos o façam ao manter uma guarda pós-cópula. Com isso, é possível observar em grupos competitivos desde displays para fêmeas até comportamentos agressivos em relação a outros machos (Tyack \& Whitehead, 1983; Clapham, 1996). Clapham (1992), contudo, notou que machos podem cooperar em seu esforço para assegurar acesso às fêmeas. Foi observado que comportamentos agonísticos - como bater com a nadadeira caudal na água, estocada de cabeça, deslocamento físico do escorte principal, soltar bolhas por baixo d'água - são mais comum em grupos de adultos com quatro ou mais indivíduos e sem filhotes (Tyack \& Whitehead, 1983; Baker \& Herman, 1984; Lunardi et al., 2008). O comportamento agressivo é influenciado pela sazonalidade e tende a diminuir ao longo da estação (Backer, 1984). O pico da frequência de agressões provavelmente está associado ao aumento da densidade e à mudança fisiológica de machos e fêmeas referente à reprodução (Baker \& Herman, 1984).

Poliginia é o acesso de um macho a muitas fêmeas. Esse conceito pode estar associado a uma diversidade de formas de obter acesso a fêmeas, tais como defesa de grupo de fêmeas receptivo (defesa de fêmeas), defesa de território com recursos que atraem fêmeas, defesa de um território ou arena para exibição (sem alimentos ou recursos que possam ser de interesse da fêmea), Outra forma seria a busca ativa por fêmeas receptivas (Alcock, 2011) 
Clapham (1996) sugere o termo "floating lek" (arena flutuante) para definir o sistema de acasalamento de Jubartes, englobando conceitos da dominância poligínica do macho, onde se observam a impossibilidade da defesa de recursos e muitas fêmeas, a ausência de cuidado parental por parte do macho, a ocorrência de displays padrão de machos e o envolvimento de machos em competição direta por acesso às fêmeas. Também engloba conceitos do sistema de acasalamento em lek como: existência de uma arena de disputa por fêmeas, ausência de recursos no território dos machos, oportunidade para fêmeas escolherem machos, displays epigâmicos executados por machos. O problema é que no acasalamento em lek clássico os machos estabelecem territórios, sendo que o território central é ocupado por indivíduos em posição mais elevada no ranking e que vão ter maior sucesso reprodutivo, fato que não ocorre com jubartes (Clapham, 1996).

As diferentes condições de estado visível de saúde (individuo com lesões marcadamente aparentes, individuo sem lesões aparentes), como cicatrizes na nadadeira dorsal, são um possível indicador de status social. Chu \& Nieukirk (1988) observaram cicatrizes na nadadeira dorsal, mais comum em machos, sugerindo que as mesmas seriam o resultado da competição intrassexual por parceiros (Chu \& Nieukirk, 1988)

\section{Fisiologia do Estresse}

Uma grande variedade de fatores estressores pode alterar a secreção de hormônios hipofisários. Esses hormônios regulam diretamente fatores associados ao bem estar tais como crescimento, reprodução, resistência a doenças, desenvolvimento (Moberg, 1987). Estímulos estressantes resultam na transmissão de impulsos nervosos ao hipotálamo, liberando corticotrofina que, ao chegar à hipófise, libera hormônios adrenocorticotróficos (ACTH), estimulando, por sua vez, a síntese e liberação de corticosteróides pelo córtex das adrenais: cortisol e corticosterona. Corticosteróides são liberados durante uma variedade de situações estressantes: como esses hormônios modulam muitos sistemas biológicos, suas funções são alteradas em uma condição de estresse. Não é certo, entretanto, que ocorram respostas adreno corticais para todas as situações de estresse (Moberg, 1987). É interessante buscar respostas biológicas que 
identificam cada tipo de estressor, e não identificar uma única medida para todos os fatores estressores (Moberg, 1987).

O córtex pré frontal é onde residem as funções executoras que incluem memória, controle inibitório, mudança flexível do foco da atenção, possibilitando raciocínio, planejamento, resolução de problemas, regulando emoções e modulando o comportamento em resposta às contingências ambientais (Blair \& Raver, 2012). O córtex pré-frontal está conectado a estruturas límbicas e do tronco cerebral associados a respostas estressoras e a excitação emocional. A mudança nos níveis de neurotransmissores que geralmente são determinados pela resposta fisiológica do estresse regula a atividade sináptica do córtex Pré-frontal: em elevados ou baixos níveis de excitação estressora a atividade do córtex pré-frontal é reduzida e com ela as funções executoras (Blair \& Raver, 2012); já em níveis moderados a excitação estressora leva a um aumento da atividade sináptica no Córtex Pré-frontal e as funções executoras são favorecidas (Blair \& Raver, 2012).

Técnicas não invasivas para acesso à funções reprodutivas e adrenais encontramse bem estabelecidas para uma grande diversidade de mamíferos terrestres, muitos trabalhos foram desenvolvidos pela coleta de hormônios a partir de material fecal, urina e saliva (Hogg, et al., 2009). A coleta de muco pulmonar presente no borrifo de cetáceos surge como uma metodologia não invasiva alternativa de acesso a hormônios reprodutivos e adrenais (Hogg, et al., 2009). Funções endócrinas dos misticetos são pouco conhecidas, amostras fecais têm sido usadas para determinar concentrações de hormônios reprodutivos e corticosteróides como é o caso da baleia-franca do atlântico norte, Eubalena glacialis, (Hunt, et al., 2006). Trabalhos também foram realizados com odontocetos de cativeiro para o acesso das funções endócrinas a partir de material salivar em falsas orcas, Pseudorca crassidens, (Atkinson et al. 1999), e golfinho nariz de garrafa, Tursiops truncatus (Hogg et al. 2005); urina em orcas, Orcinus orca (Robeck et al. 1993). A literatura carece de trabalhos publicados com misticetos de vida livre referente às funções endócrinas, principalmente no que diz respeito aos níveis de cortisol. A coleta de borrifo é uma alternativa viável e interessante na investigação de aspectos fisiológicos que podem afetar o comportamento. 


\section{Comportamento e Possíveis Interações Com o Estresse}

Flutuações do nível de cortisol no sangue dependem de muitos fatores ambientais como dieta, clima e estagio fisiológico do desenvolvimento, histórico de vida do animal (Flisinska-Bojanowska et al., 1991; Reeder \& Kramer, 2005). Períodos prolongados de fome, em espécies de vertebrados, podem gerar aumento dos níveis de cortisol no sangue e inibir comportamento reprodutivo (Lynn et al., 2010; ). A resposta a um agente estressor é uma mistura do conjunto: resposta fisiológica e comportamental que servem para amenizar o efeito estressor e restabelecer a homeostase (Reeder \& Kramer, 2005).

A temporada de acasalamento pode ser um momento estressante para indivíduos de algumas espécies, principalmente para machos. Sands \& Creel (2004) ao realizarem um trabalho com em vida livre no Parque Nacional de Yelowstone, verificaram que os níveis de cortisol em lobos dominantes eram muito maiores que os de hierarquia inferior, e não estavam associados a altos níveis de agressão ou interação agonística. Daí, elaboram uma reflexão sobre o papel do estresse como custo da posição de dominância e não como consequência da subordinação. Foi encontrado um padrão semelhante ao de Canis lúpus em relação à dominância social, agressão e estresse para Mandril (Mandrillus sphinx) (Setchell et al, 2010). O stress tem papel relevante na fisiologia e no comportamento de animais que se encontram em período de acasalamento envolvendo um gasto energético extra voltado para a reprodução. A elevação dos níveis de estresse em ambientes naturais permite ao animal responder a desafios sociais, físicos e ambientais (Reeder \& Kramer, 2005). Para fêmeas de mamíferos, a gravidez é um evento que também altera os níveis de cortisol do sangue. Os níveis de cortisol tendem a aumentar durante a gravidez para várias espécies de mamíferos, como ovelhas, cavalos, lobos (Bell et al., 1991; Flisinska-Bojanowska et al., 1991; Sands \& Creel, 2004).

\section{Distúrbios de comportamento e interação com humanos}

Distúrbios frequentes nos comportamentos críticos de uma espécie tais como descanso, alimentação e reprodução, podem diminuir seu fitness - capacidade de um organismo para sobreviver e reproduzir no seu meio - (Scheidat, 2004). Baleias jubarte podem aumentar sua velocidade de natação e diminuir seu intervalo de 
respiração ao serem incomodadas por embarcações. Como não se alimentam em áreas de reprodução, são excessivamente vulneráveis ao gasto energético extra causado por distúrbios (Scheidat, 2004; Morete et al., 2007). Comportamentos agonísticos podem aparecer diante da aproximação de embarcações (Scheidat, 2004). Herman \& Backer (1989) sugeriram que a densidade de jubartes é inversamente relacionada à quantidade de barcos em tráfego e à atividade humana. A forma como uma embarcação é conduzida, o tipo de embarcação e o ruído gerado podem influenciar no comportamento de jubartes (Backer \& Herman, 1989). Contudo, ao serem comparadas duas categorias de embarcação - turismo e pesquisa - em um trabalho feito no litoral norte da Bahia, não houve diferença na probabilidade de ocorrência desses comportamentos (Simões et al., 2005). Também foram testadas distintas metodologias de aproximação e de permanência que não tiveram diferenças comportamentais significativas. Os autores, porém, afirmam que é preciso ter cautela com esse resultado por basear-se em probabilidade de ocorrência e não em frequências comportamentais (Simões et al., 2005).

\section{Objetivos}

O presente estudo pretende investigar diferenças nos aspectos comportamentais dos diferentes grupos sociais de baleia-jubarte ao longo da estação reprodutiva, como os grupos se distribuem geograficamente ao longo dos meses e os possíveis efeitos da fisiologia do estresse nos diferentes contextos sociais e sua possível relação com os comportamentos.

\section{Objetivos Específicos}

1) Testar diferenças entre as frequências de avistamentos de filhotes e dos grupos sociais ao longo dos meses da estação reprodutiva e as suas distribuições geográficas, se em torno do Parque de Abrolhos ou áreas próximas ao continente, como os recifes.

2) Investigar diferenças nas atividades comportamentais nos grupos competitivos, grupos com fêmea escorte e filhote, fêmea com filhote e indivíduos solitários no meio (agosto e setembro) e fim (outubro e novembro) da estação reprodutiva. 
3) Comparar diferenças de comportamentos observados em relação à composição dos grupos e também em relação aos meses da estação reprodutiva (agosto, setembro, outubro e novembro).

4) Investigar diferenças entre níveis do hormônio do estresse (cortisol) em relação aos grupos com fêmea escorte e filhote, fêmea com filhote e indivíduos solitários no meio (agosto e setembro) e fim (outubro e novembro) da estação reprodutiva.

5) Avaliar a correlação entre os níveis de cortisol (hormônio do estresse) e taxas de comportamentos, como também avaliar a correlação entre os níveis de cortisol (hormônio do estresse) e o numero de indivíduos nos grupos sociais.

\section{Materiais e Métodos}

\section{Aspectos Éticos}

A metodologia do presente estudo foi submetida e aprovada pelo comitê de ética de uso animal em pesquisa da Universidade de Brasília, ver certificado no apêndice II.

\section{Área de estudo}

O estudo ocorreu no banco dos Abrolhos, costa sul do estado da Bahia. A área encontra-se em uma plataforma continental, é conhecida como a mais rica em espécies de recifes de coral do Atlântico Sul (ICMBio, 2015).

Suas espécies de coral podem formar colunas coralinas conhecidas como chapeirões, que contribuem com a irregularidade das profundidades na área. A região possui águas rasas com profundidades menores que 30m e a borda da plataforma pode chegar a 70m; a região entre os recifes costeiros e a costa possui profundidade inferior a $15 \mathrm{~m}$, o canal de Abrolhos, região entre os recifes costeiros e as ilhas de Abrolhos, pode chegar a 30m de profundidade (Silva, et al, 2013).

O foco do esforço amostral ocorreu no canal de Abrolhos e ao redor da área do Parque Nacional Marinho dos Abrolhos, figura 1. 
Figura 1. Área de amostragem dos comportamentos de Megaptera novaeangliae

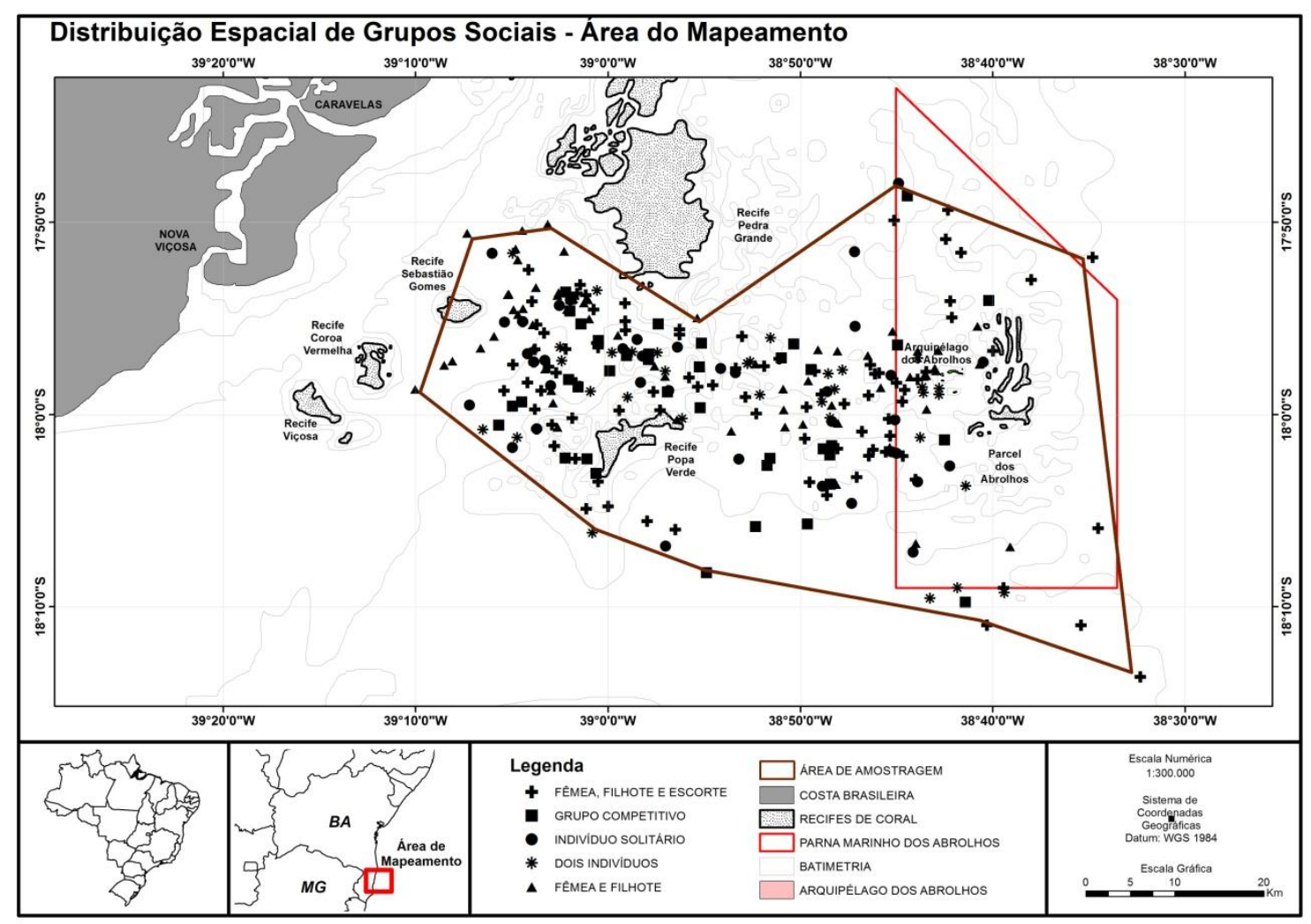

As campanhas tinham como ponto de partida o porto de Caravelas, com saída às 7h da manhã. A abertura das amostragens começava assim que a embarcação saia do canal, antes dos recifes costeiros, mas os animais só começavam a ser avistados entre o recife de Sebastião Gomes e recife de Pedra grande. A coleta dos dados ocorreu ao longo da estação reprodutiva das baleias Jubarte, entre agosto e novembro, de 2014. Foi realizado um total de 10 campanhas, cada campanha teve uma duração média de 3 dias. O esforço amostral foi distribuído de forma diferenciada, 3 campanhas em agosto, 2 em setembro, 2 em outubro e 3 em novembro (Tabela 1). As observações ocorreram somente em condições de tempo bom sem chuva, sem alta intensidade de ventos e sem ondulação elevada.

Tabela 1. Esforço amostral, número de avistamentos e número de baleias adultas avistadas durante a época do estudo.

\begin{tabular}{ccccccccccc}
\hline Campanhas & 1 & 2 & 3 & 4 & 5 & 6 & 7 & 8 & 9 & 10 \\
\hline Avistamentos* & 28 & 27 & 23 & 22 & 28 & 22 & 21 & 24 & 12 & 6 \\
$\mathrm{~N}^{\circ}$ de Adultos & 69 & 78 & 91 & 91 & 84 & 41 & 37 & 57 & 26 & 12 \\
Tempo de procura (min) & 1372 & 1496 & 1264 & 2599 & 1470 & 1091 & 1149 & 2191 & 457 & 466 \\
Tempo de observação (min) & 673 & 693 & 585 & 528 & 697 & 469 & 487 & 724 & 334 & 130 \\
\hline *O número de avistamentos equivale ao número de etogramas.
\end{tabular}




\section{Definições de variáveis independentes e dependentes}

As baleias - jubarte podem ser encontradas no período reprodutivo em uma variedade de agrupamentos sociais. A compreensão das diferenças comportamentais entre esses animais vem sendo discutida na literatura em função do grupo social a qual esse animal pertence.

Assim, foram definidos como variáveis independentes os diferentes grupos sociais observados. Dessa forma, o estudo separou agrupamentos sociais em 5 categorias: um indivíduo adulto solitário (IS), dois indivíduos adultos (DI), fêmea com filhote (FF), fêmea com filhote e escorte (FFE), grupo competitivo (GC). A definição das categorias foi feita a partir de trabalhos anteriores (Tyack \& Whitehead, 1983; Baker \& Herman, 1984; Mobley \& Herman, 1985; Clapham et al., 1992; Engel, 1996; Morete, 2007). Grupos sociais afiliam-se e desafiliam-se ao longo da temporada, de maneira mais intensa no pico da estação reprodutiva; a duração em que escortes acompanham fêmeas com filhote é de algumas horas e grupos maiores mudam de composição com maior frequência (Mobley \& Herman, 1985). A composição dos grupos sociais está em constante mudança, com a exceção das fêmeas com filhotes que permanecem juntos nas áreas de reprodução (Mobley \& Herman, 1985). Grupos competitivos são bastante ativos, movem-se rápido e são constituídos de três ou mais baleias adultas nadando próximas em uma mesma direção (Tyack \& Whitehead, 1983; Baker \& Herman, 1984; Clapham et al., 1992). Definir grupo competitivo é algo complexo, pequenos grupos de machos podem ser formados e exibir comportamentos semelhantes ao dos grupos competitivos (Tyack \& Whitehead, 1983; Baker \& Herman, 1984; Clapham et al., 1992). Indivíduos nadando próximo às fêmeas com filhote foram categorizados como escortes, seguindo orientação de estudos moleculares para identificação de gênero que vem apontando que todos são machos (Medrano, 1994).

A definição das variáveis dependentes envolveu a classificação dos comportamentos. Os comportamentos foram divididos em eventos comportamentais que se caracterizam como comportamento instantâneo ou breve - saltos, batidas de nadadeiras, batidas de cabeça, mergulho com exposição caudal - e estados comportamentais - comportamentos com maior duração de tempo ou de longa sequência em que um indivíduo ou grupo está engajado, como natação, repouso, 
exposição caudal parada. - (Altmann, 1974). Os estados comportamentais foram categorizados em estados ativos que envolvem padrões de natação, inativo que seria o repouso e sociais que estariam relacionados à interação social com outros indivíduos; e os comportamentos classificados como eventos comportamentais foram agrupados em eventos agonísticos que envolve níveis de agressividade, ativos-exploratórios associado a padrões de movimento e displays sociais. As definições de estados e eventos comportamentais foram feitas com base em trabalhos anteriores (Kaufman \& Forestell, 1993; Engel, 1996; Morete, 2007), e a partir das observações feitas em campo, como indicado na Tabela 2.

Tabela 2. Descrições e legendas dos estados e eventos comportamentais que foram descritas por diferentes autores e podem ser encontrados neste estudo.

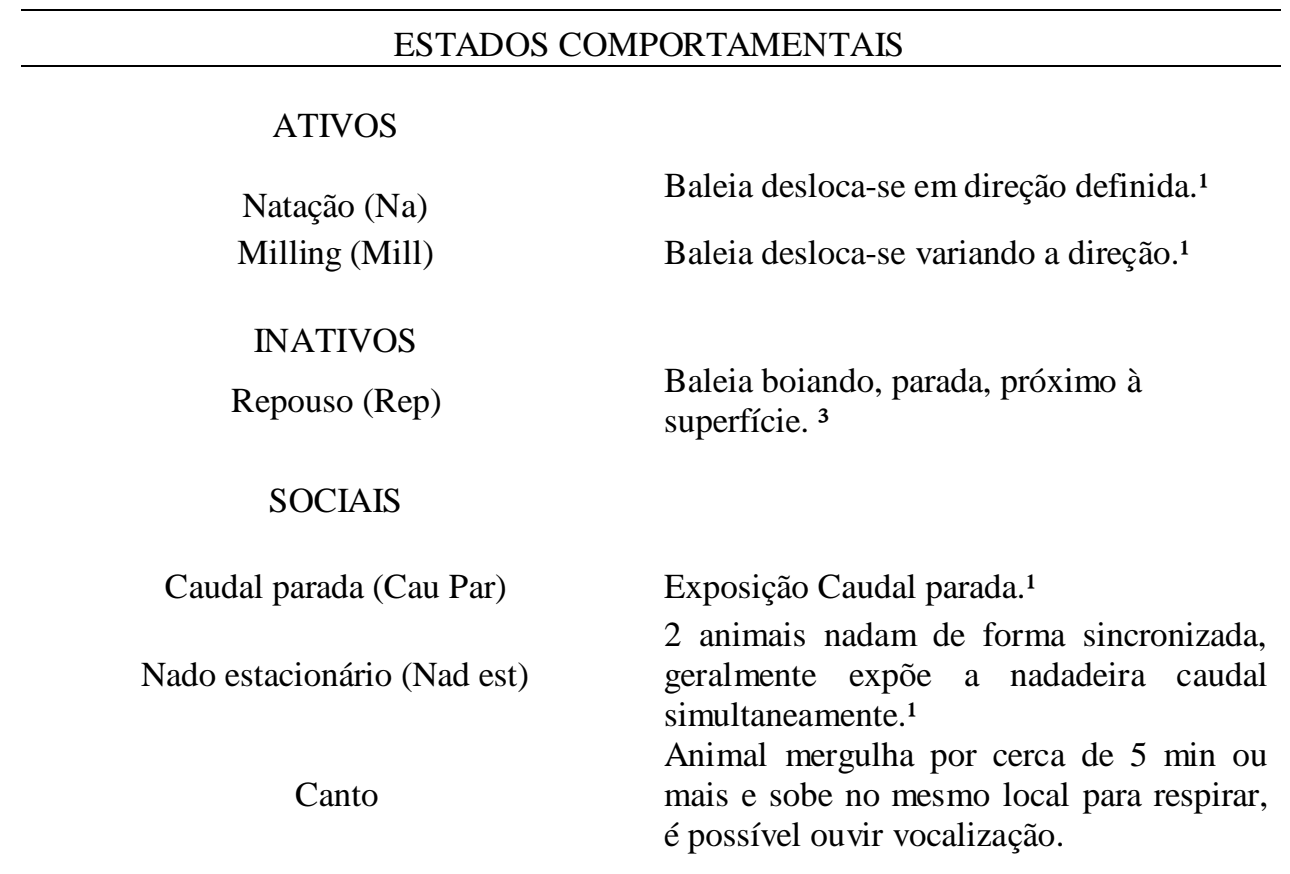

EVENTOS COMPORTAMENTAIS

AGONÍSTICOS

Golpe de cabeça (G. Cab)

Erguimento de cabeça (Erg Cab)

Exalar bolhas (Ex Bol)

Ruido respiratório (Ru Resp)

Batida de peitoral (Bat Peit)
Animal projeta a cabeça contra outro indivíduo. ${ }^{2}$

Animal sai com parte da cabeça fora d'água em movimento rápido e volta a mergulhar. Pode inflar a região gular. ${ }^{2}$

Exalar bolhas pelo orifício respiratório. ${ }^{2}$

Ruído agonístico emitido quando o animal sobe à superfície para respirar. ${ }^{2}$

Baleia bate nadadeira peitoral na superfície da água. ${ }^{123}$ 
Batida lateral caudal (Bat Lat Cau)

Batida de pedunculo caudal (Bat P Cau)

Batida de caudal (Bat Cau)

DISPLAYS SOCIAIS

Salto (ST)

Batida de cabeça (Bat $\mathrm{Cab}$ )

Spy Hop (S Hop)

Balanço de cabeça (Bal Cab)

Rolamento (Rol)

Exposição de peitoral (Exp Peit)

\section{ATIVOS EXPLORATÓRIOS}

Serpentear (Snak)

Mergulho próximo com mudança de direção (Merg M Dir)

Indução de direção (I Dir)

Fricção peitoral (Fric Peit)

Mergulho com exposição caudal (Merg Exp Cau)

Mudança de direção (Mud D Dir)

Exibição da Nadadeira peitoral (Exi peit)
Baleia bate a nadadeira caudal lateralmente e com agressividade em direção a outra baleia. ${ }^{1}$

Pedunculo caudal é erguido batendo dorsal e ventralmente na superfície da água. ${ }^{2}$

Nadadeira caudal é erguida no ar e golpeia a superfície da água. 123

Exposição da maior parte do corpo fora d'água, pode envolver giro parcial ou total ao redor do eixo crânio caudal do corpo da baleia ${ }^{1} 3$

Baleia eleva a cabeça fora da água e golpeia a superfície. ${ }^{3}$

Comportamento conhecido como espiar, a baleia ergue parte anterior do corpo surgindo de forma vertical em relação à água. 123

Movimentar a cabeça de um lado para outro na superfície da água. ${ }^{1}$

$\mathrm{O}$ animal rola na superfície da água expondo o ventre e nadadeiras peitorais. ${ }^{1}$

Nadadeiras peitorais paradas e expostas fora d'água. ${ }^{1}$

Serpentear na superfície da água expondo o dorso e a cabeça. ${ }^{1}$

Baleia mergulha próximo ao barco e muda de direção.

A mãe posiciona-se abaixo do filhote e o induz a mudar de direção escoltando-o com o corpo.

Fricção entre nadadeiras peitorais de dois indivíduos. ${ }^{1}$

Baleia expõe a nadadeira caudal ao submergir. ${ }^{3}$

Mudança de direção da navegação da baleia.

Baleia exibe nadadeira peitoral com o corpo posicionado lateralmente. ${ }^{3}$

Nota:Referências dos comportamentos - 1 Kaufman \& Forestell (1993), 2 Engel (1996), 3 Morete (2007).

Comportamentos sem referência foram observados ao longo da campanha.

Observação:

a) Quando o filhote apresentou os referidos comportamentos acrescentou-se a sigla Fi; b) $\mathrm{O}$ animal quando mergulha e fica sem retornar à superfície por no mínimo 3 minutos foi categorizado como comportamento "não visível".

Ainda para avaliar atividade comportamental, foi elaborada uma leitura dos dados em forma de taxa de categoria de estado e evento comportamental por hora e por 
individuo, para evitar as deformações das tendências subjacentes ao excesso de tempo de observação aplicadas em alguns indivíduos em relação a outros, visto que não havia tempo máximo definido de observação, apenas tempo mínimo de observação, de 10 minutos. O tempo máximo seguiu as oportunidades de conveniência de observação, foi de 70 minutos para o presente estudo.

Conforme a literatura e por serem comportamentos com topografia e significado diferenciados, os comportamentos dos filhotes foram separados dos comportamentos dos adultos.

Assim, para as categorias de estados e eventos comportamentais utilizou-se uma taxa comportamental que considerou somente os comportamentos de adultos e foi elaborada conforme a seguinte formula: (taxa de estados ou eventos comportamentais de adultos $=$ total da categoria de estado ou do evento comportamental observado $\mathrm{x} 60$ minutos / tempo de observação em minutos).

Por outro lado, para a análise considerando todo o aglomerado dos eventos comportamentais somente dos animais adultos, foi utilizada uma taxa comportamental concomitantemente por indivíduo e por hora. Nessa condição de aglomerar todas as categorias de eventos comportamentais, denominamos categoria de comportamentos aéreos ou superficiais. Essa taxa foi calculada da seguinte maneira: [(taxa de comportamentos superficiais $=$ total de comportamentos superficiais $\mathrm{x} 60$ minutos $/$ tempo de observação em minutos) / número de indivíduos adultos do grupo social observado] A partir dos comportamentos superficiais, foi possível analisar toda a atividade comportamental dos animais de forma a conhecer o número médio de taxa comportamental por hora de cada indivíduo dentro dos grupos sociais nos diferentes meses da estação. Dessa forma, a taxa de comportamentos superficiais foi usada para comparar os níveis de atividade comportamental dos diferentes grupos sociais ao longo da estação.

Com o intuito de compreender as diferenças entre as frequências de observação dos grupos sociais, comportamentos e níveis de estresse ao longo da estação reprodutiva, foram definidos também como variáveis independentes os meses da estação reprodutiva. Assim, analisamos as diferenças entre as frequências de observação em cada mês da estação reprodutiva (agosto, setembro, outubro e novembro) ou blocos de meses do meio (agosto-setembro) e do fim (outubro-novembro) da estação. 


\section{Coleta de dados comportamentais}

Um barco com seis observadores realisou busca ativa por baleias na área entre Caravelas (BA) e o arquipélago de Abrolhos. Uma pessoa ficou responsável por registrar os comportamentos nas planilhas de dados. Após o avistamento, o barco aproximava-se lentamente do grupo mais próximo e, a partir de uma distância de 300m, os grupos eram identificados, o ponto no GPS era marcado e os comportamentos começavam a ser registrados.

Para o registro dos comportamentos utilizou-se o protocolo de grupo focal com registro contínuo, sugerido por Mann (1999), como referência. Deste modo, muitos indivíduos podem ser amostrados simultaneamente e questões sobre escala temporal e espacial da estrutura social podem ser investigadas. A escolha deste protocolo deve-se à dificuldade de identificar individualmente os animais no momento das observações. Apesar de Mann (1999) sugerir que o protocolo de amostragem de grupo requer tempo mínimo de amostragem de 30 minutos, o presente trabalho considerou observações com tempo mínimo de 10 minutos como válidas, em conformidade a outros autores que consideram tempo mínimo entre 10 e 15 minutos (Felix, 2004; Pacheco et al., 2013). Entretanto o maior tempo de observação em nosso estudo foi de 70 minutos e o tempo médio de observação foi de 21 minutos. É importante destacar que a presença do barco muito próxima aos grupos pode interferir no comportamento dos animais e alterar padrões de atividade naturais.

Utilizou-se metodologia hibrida para registro sistemático de estados e eventos comportamentais. Para estados comportamentais - comportamentos duradouros em que o tempo gasto com a atividade é relevante - amostragem de grupo focal mostrou-se mais interessante, pois permite acesso contínuo à atividade do grupo (Altmann, 1974; Mann, 1999). No caso de eventos comportamentais que ocorrem próximo à superfície da água, a metodologia utilizada foi a de registro de todos os eventos - "all event sampling" - em que comportamentos são infrequentes, suas manifestações são facilmente registradas, independente do número de indivíduos, sendo que todos os esforços devem ser feitos para identificar os sujeitos (Altmann, 1974; Mann, 1999). De modo geral, a metodologia utilizada no trabalho pode ser definida como uma amostragem contínua de estados e eventos comportamentais,

Um etograma foi elaborado para o registro de estados e eventos comportamentais nas categorias de comportamento referidas anteriormente. 
Informações como data, horário de início e fim da observação, tipo de grupo, número de indivíduos no grupo, número de filhotes no grupo e o local (ponto de GPS) em que o grupo foi encontrado também foram registrados no etograma.

\section{Aferição do cortisol}

O cortisol foi coletado a partir do jato de ar e muco do sistema respiratório da jubartes, liberado na expiração, ao misturar-se com a água do mar forma os borrifos.

As metodologias utilizadas no presente trabalho são consideradas não invasivas, foram utilizadas em outros estudos para coleta de bactérias respiratórias (Acevedo et al., 2009) e hormônios esteróides (Hogg et al., 2009) de cetáceos de vida livre.

O método se caracteriza por duas formas de coleta. A primeira utilizou-se de um bastão de alumínio anexado a uma placa de acrílico opaca. Para cada grupo amostrado a placa de acrílico foi envolvida por uma película de papel filme, conforme Apêndice III, figura 2. Quando o grupo encontrava-se na frente do barco, com o vento no sentido contrário à navegação, foi possível coletar amostras de borrifo. Após a coleta, o papel filme era substituído para evitar contaminação das amostras. Inspirado no trabalho de Acevedo (2009) que utilizou, com sucesso, um helicóptero aeromodelo para coletar borrifo. O presente trabalho tentou coletar borrifo com um Phanton Drone DJI. Inseriuse uma placa coletora e algumas boias para não perder o equipamento caso caísse na água, apêndice III, figura 3.

O borrifo, ao ser captado, foi coletado e armazenado em um ependorfe, devidamente identificado e armazenado a baixas temperaturas. Após o fim da estação reprodutiva das Jubartes de 2014, as amostras foram encaminhadas ao laboratório Axys Análises onde foi adicionado $0,5 \mathrm{ml}$ de água ultra pura para cada tubo, centrifugados por 5 minutos e o líquido foi submetido à análise pelo método ELISA por competição para determinar quantidade de cortisol em soro e plasma humano.

O laboratório analisou as amostras com legendas cegas para seu entendimento. Estas faziam sentido apenas para o presente pesquisador. 


\section{Métodos estatísticos}

Para avaliar diferenças em relação à frequência de observação dos grupos e suas distribuições geográficas ao longo dos meses da estação, foi utilizado o teste quiquadrado de Pearson. Para a identificação das diferenças entre pares de meses específicos foi utilizada a correção de Bonferoni. A mesma metodologia foi adotada na avaliação de diferenças na distribuição dos grupos sociais (IS, DI, FF, FFE e GC) ao longo dos meses e também entre áreas de amostragens.

Para comparar as taxas de comportamentos superficiais entre diferentes estações, grupos sociais, presença ou ausência de filhotes e áreas geográficas de amostragens, utilizou-se o teste Kruskal Wallis.

Para avaliar as diferenças entre os cinco grupos sociais em relação à expressão das categorias comportamentais de estados e eventos, como também as diferenças das expressões ocorridas entre os quatro meses da estação reprodutiva utilizamos a ANOVA para comparações par a par; e MANOVA para comparações múltiplas de efeitos e de interações. Ambas foram seguidas da avaliação a posteriori do teste Tuckey HSD para indicações das diferenças.

Para avaliar os níveis de cortisol entre os diferentes meses da estação utilizou-se o teste Kruskal Wallis. A mesma metodologia foi adotada na avaliação dos níveis de cortisol para taxas de comportamento superficial, número de adultos no grupo social, gênero do adulto (Fêmea, escorte, indivíduos sem identificação).

Foi realizado teste de correlação de Pearson para avaliar correlação entre níveis de cortisol e taxa de comportamento, o mesmo teste também foi usado para avaliar a correlação entre os níveis de estresse e o número de indivíduos nos grupos sociais.

Em todos os testes adotou-se o nível de significância de 0,05 . As análises foram realizadas no software SPSS (versão 21.0). 


\section{Resultados}

Frequências de avistamentos dos filhotes e de grupos sociais ao longo da estação reprodutiva e suas distribuições geográficas

Ao longo de todas as campanhas foram avistados 586 adultos, levando-se em consideração todos os grupos observados, o número médio de adultos foi de 2,1.

Foram encontrados 181 filhotes, que compuseram 64\% do total de grupos avistados. Dentre os 49 grupos competitivos registrados, 19 contavam com a presença de filhotes. De modo geral, a proporção de filhotes avistados variou significativamente entre os meses avaliados (Tabela 3).

Nas comparações entre os pares de meses, verificou-se que a frequência de filhotes é significativamente menor para o mês de agosto em relação a setembro, outubro e novembro (valor de $\mathrm{p}<0.001$ ).

Tabela 3. Frequência de avistamentos de filhotes nos grupos sociais por mês ao longo da estação reprodutiva.

\begin{tabular}{ccccccccccc}
\hline $\begin{array}{c}\text { Avistamentos } \\
\text { de grupos }\end{array}$ & Agosto & Setembro & Outubro & Novembro & Total Geral \\
\hline & Freq. & Perc. & Freq. & Perc. & Freq. & Perc. & Freq. & Perc. & Freq. & Perc. \\
$\begin{array}{c}\text { Grupos sem } \\
\text { filhote }\end{array}$ & 51 & 51,5 & 22 & 30,6 & 13 & 23,6 & 15 & 26,6 & 101 & 35,8 \\
$\begin{array}{c}\text { Grupos com } \\
\text { filhote }\end{array}$ & 48 & 48,5 & 50 & 69,4 & 42 & 76,4 & 41 & 73,2 & 181 & 64,2 \\
$\begin{array}{c}\text { Total de } \\
\text { grupos }\end{array}$ & 99 & 100 & 72 & 100 & 55 & 100 & 56 & 100 & 282 & 100 \\
\hline
\end{tabular}

Nota: Teste Qui-quadrado de Pearson $\mathrm{p}<0,001$.

Foram acompanhados 282 grupos sociais ao longo da temporada reprodutiva de 2014. De um total de 226 horas de esforço amostral, distribuído ao longo dos meses (agosto a novembro), obteve-se um total de 88 horas de observação dos diferentes grupos sociais. 
O grupo social avistado com maior frequência ao longo da temporada foi o de fêmea acompanhada de escorte e filhote, que compuseram 88 grupos $(31,2 \%)$, seguido por fêmea e filhote com 75 grupos (26,6\%), 44 grupos competitivos (15,6\%), 41 indivíduos solitários (14,5\%), 34 grupos com 2 indivíduos adultos (12,1\%).

A frequência dos avistamentos dos grupos sociais registrados em cada mês da estação reprodutiva mostrou-se significativamente diferente, conforme Teste Quiquadrado de Pearson $\mathrm{p}<0,001$. (Tabela 4 e figura 4), isto é, a proporção de avistamentos de grupos competitivos foi significativamente maior para os meses de agosto e setembro quando comparadas ao mês de outubro. Por outro lado, a proporção de avistamentos de fêmeas com filhote foi significativamente maior para o mês de outubro em relação aos meses de agosto e setembro. O teste também foi significativo para uma maior proporção de fêmeas com filhote em novembro, quando comparado ao mês de agosto.

Tabela 4. Frequência dos avistamentos de grupos sociais durante os meses da estação reprodutiva.

$\begin{array}{lllll}\text { Grupo social } & \text { Agosto } & \text { Setembro } & \text { Outubro } & \text { Novembro Total Geral }\end{array}$

Freq. Perc. Freq. Perc. Freq. Perc. Freq. Perc. Freq. Perc.

$\begin{array}{lcccccccccc}\text { DI } & 21 & 21.2 & 6 & 8.3 & 4 & 7.3 & 3 & 5.4 & 34 & 12.1 \\ \text { FF } & 13 & 13.1 & 16 & 22.2 & 26 & 47.3 & 20 & 35.7 & 75 & 26.6 \\ \text { FFE } & 30 & 30.3 & 28 & 38.9 & 14 & 25.5 & 16 & 28.6 & 88 & 31.2 \\ \text { GC } & 21 & 21.2 & 14 & 19.4 & 2 & 3.6 & 7 & 12.5 & 44 & 15.6 \\ \text { IS } & 14 & 14.1 & 8 & 11.1 & 9 & 16.4 & 10 & 17.9 & 41 & 14.5 \\ \text { Total Geral } & 99 & 100.0 & 72 & 100.0 & 55 & 100.0 & 56 & 100.0 & 282 & 100.0\end{array}$


Figura 4. Frequência de avistamento dos grupos sociais ao longo da estação

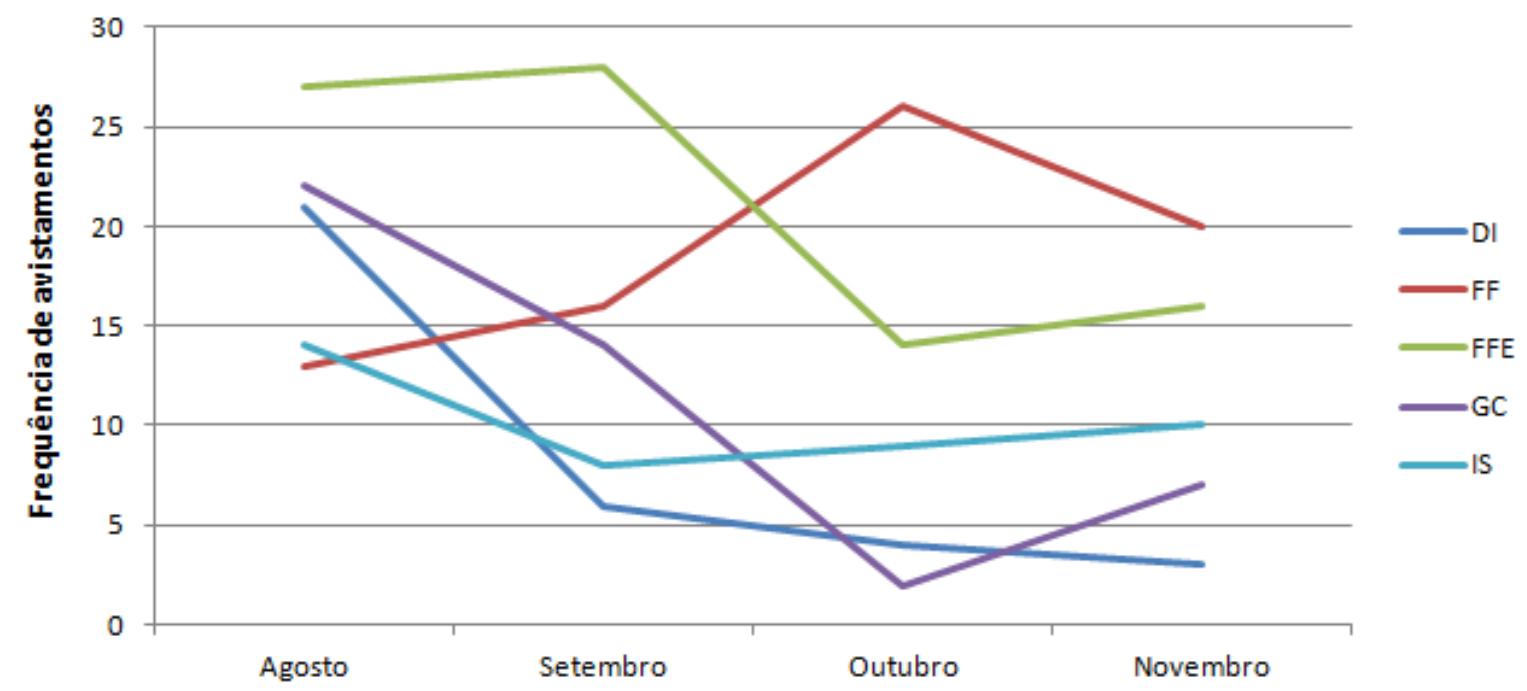

A distribuição geográfica dos avistamentos foi registrada a partir dos pontos marcados no GPS no momento em que o barco aproximava-se dos grupos sociais.

A área de amostragem foi dividida em duas áreas por uma linha imaginária.

A primeira área, definida como Recifes Costeiros, vai da costa até os Recifes de Pedra Grande e Popa verde.

A segunda área foi definida como Canal de Abrolhos e encontra-se entre os recifes de Pedra Grande e Popa verde, e a área do Parque nacional Marinho dos Abrolhos.

Foram encontrados ao longo de toda a temporada 134 grupos sociais na área dos recifes costeiros e 148 grupos sociais na área do Canal dos Abrolhos (ver mapas, Figura $5)$. 
Figura 5. Mapas de registros dos grupos sociais por mês da estação reprodutiva
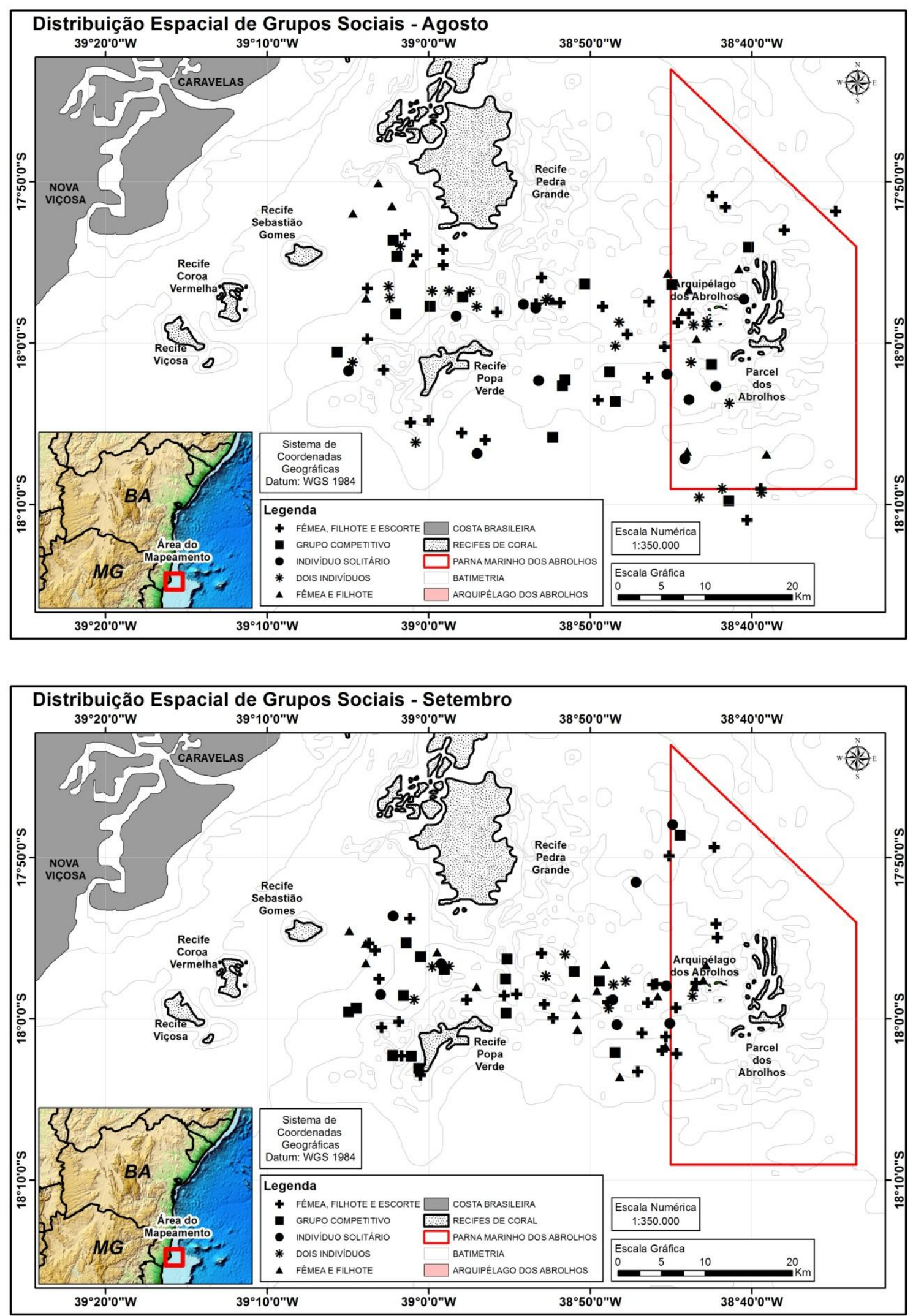

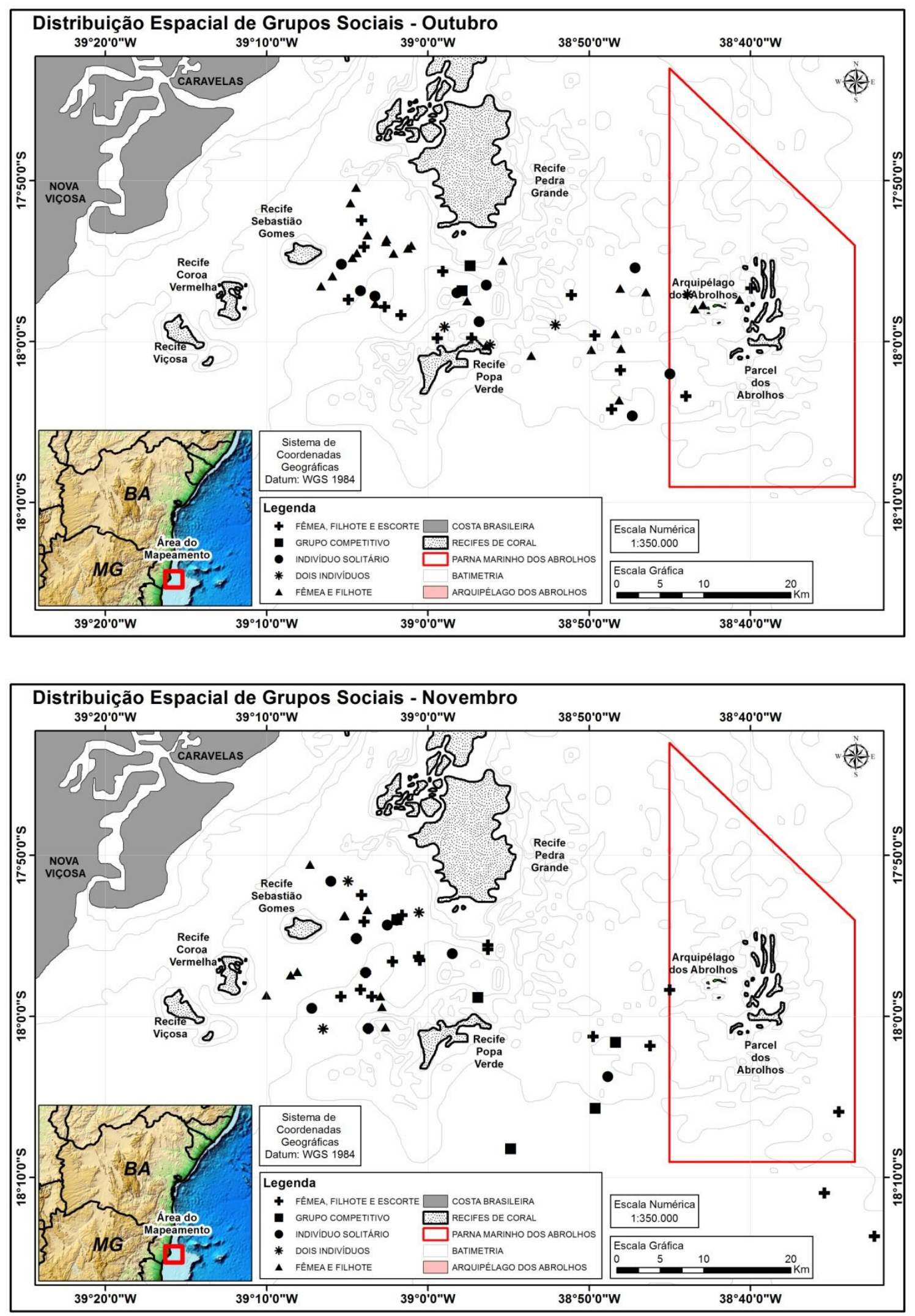

Não houve diferença significativa entre a distribuição geográfica dos avistamentos totais dos grupos sociais entre áreas próximas aos Recifes Costeiros e a área do Canal dos Abrolhos p=0,946 (Qui-quadrado de Pearson $x 2=0,740$ ). 
Por outro lado houve diferença significativa na distribuição geográfica dos avistamentos quando as amostras foram avaliadas por mês $\mathrm{p}<0,01$ (Qui-quadrado Pearson $x 2=15,785$ ), com uma maior frequência de avistamentos de grupos sociais próximo ao Canal de Abrolhos em agosto, em relação a outubro e novembro; e em setembro em relação a novembro. Enquanto que nos Recifes Costeiros ocorreu uma frequência maior de avistamentos de grupos sociais em novembro do que em agosto e setembro; e em outubro uma frequência de avistamentos maior do em agosto.

\section{Analise das taxas e estados comportamentais por grupo social e ao longo dos meses da estação reprodutiva}

Segundo a MANOVA os grupos sociais expressaram entre eles e entre os meses da estação reprodutiva taxas comportamentais de estados e eventos significativamente diferentes.

Entre os grupos ocorreu uma expressão comportamental significativamente diferente de taxa de estados ativos $(\mathrm{p}<0,001)$, taxa de estados inativos $(\mathrm{p}<0,002)$, taxas de estados sociais $(p<0,001)$ e a taxa de eventos ativos exploratórios $(p<0,001)$. Enquanto que entre os meses da estação, a expressão comportamental foi significativamente diferente para as taxas de estados ativos $(\mathrm{p}<0,049)$ e as taxas de estados sociais $(\mathrm{p}<0,001)$.

Ao avaliar o efeito de interação grupo e mês da estação reprodutiva, observaramse diferenças significativas para a expressão comportamental das taxas de estados ativos $(\mathrm{p}<0,025)$ e estados sociais $(\mathrm{p}<0,001)$, e eventos ativos exploratórios $(\mathrm{p}<0,010)$, conforme apresentado na tabela 5 .

Tabela 5. Análise MANOVA sobre as taxas comportamentais adulto/hora de estados e eventos observadas em relação aos grupos sociais, aos meses da estação reprodutiva, ao efeito interação grupo $x$ mês da estação.

\begin{tabular}{ccccc}
\hline Variáveis & Variáveis Dependentes & & & \\
Independentes & Taxas Comportamentais & gl & F & $p$ \\
\hline & Estados Ativos & 4 & 17,786 & $<0,001$ \\
GRUPOS & Estados Inativos & 4 & 4,429 & $<0,002$ \\
& Estados Sociais & 4 & 13,870 & $<0,001$
\end{tabular}


MESES DA

ESTAÇÃO
Eventos Agonísticos

Eventos Displays Sociais

Eventos Ativos Exploratórios

Estados Ativos

Estados Inativos

Estados Sociais

Eventos Agonísticos

Eventos Displays Sociais

Eventos Ativos Exploratórios

$\begin{array}{ccc}4 & 1,592 & , 177 \\ 4 & , 311 & , 871 \\ 4 & 7,663 & <0,001 \\ & & \\ 3 & 2,655 & <0,049 \\ 3 & , 456 & , 713 \\ 3 & 8,383 & <0,001\end{array}$

3

,064 ,979

$3 \quad, 522 \quad, 668$

$3 \quad, 892 \quad, 446$

$12 \quad 1,995<0,025$

$12 \quad, 442 \quad, 945$

$12 \quad 6,453<0,001$

DAPOS $x$ MESE

Estados Ativos

Estados Inativos

Estados Sociais

Eventos Agonísticos

Eventos Displays Sociais

Eventos Ativos Exploratórios
12

12

12
,517 903

,256 ,995

$2,245<0,010$

Efeito de diferença significativa $=\mathrm{p}<0,05$

Ao analisar comparações par a par entre variáveis dependentes e independentes através da ANOVA foram verificadas diferenças significativas entre os grupos sociais em relação às taxas dos comportamentos estados ativos $(p<0,001)$, estado inativo $(p<$ $0,001)$, estados sociais $(\mathrm{p}<0,001)$, eventos agonísticos $(\mathrm{p}<0,002)$ e eventos ativos exploratórios $(\mathrm{p}<0,001)$.

Ao avaliar as taxas e estados comportamentais em relação à expressão desses nos quatros diferentes meses da estação reprodutiva, a ANOVA apontou somente efeito de diferença significativa em relação à taxa de estados ativos $(p=0,020)$, conforme tabela 6 .

Tabela 6. Análise ANOVA sobre as taxas comportamentais adulto/hora de estados e eventos observados em relação aos grupos sociais e aos meses da estação reprodutiva.

\begin{tabular}{ccccc}
\hline $\begin{array}{c}\text { Variáveis } \\
\text { Independentes }\end{array}$ & $\begin{array}{c}\text { Variáveis Dependentes } \\
\text { Taxas Comportamentais }\end{array}$ & Gl & F & Sig. \\
\hline Estados Ativos & 4 & 19,944 & $<0,001$ \\
Estados Inativos & 4 & 6,206 & $<0,001$ \\
Estados Sociais & 4 & 6,828 & $<0,001$
\end{tabular}


GRUPO

$\begin{array}{lcccc} & \text { Eventos Agonísticos } & 4 & 4,387 & <0,002 \\ & \text { Eventos Displays Sociais } & 4 & 1,389 & , 238 \\ \text { Eventos Ativos Exploratórios } & 4 & 18,610 & <0,001 \\ & \text { Estados Ativos } & 3 & 3,345 & <0,020 \\ \text { MESES DA } & \text { Estados Inativos } & 3 & 2,139 & , 096 \\ \text { ESTAÇÃO } & \text { Estados Sociais } & 3 & 1,431 & , 234 \\ & \text { Eventos Agonísticos } & 3 & , 908 & , 438 \\ & \text { Eventos Displays Sociais } & 3 & 1,028 & , 380 \\ & \text { Eventos Ativos Exploratórios } & 3 & 2,327 & , 075\end{array}$

Efeito de diferença significativa $=\mathrm{p}<0,05$

As taxas adulto/hora não computam comportamentos de filhotes

O teste a posteriori Tuckey HSD, ao analisar as diferenças significativas entre os grupos em relação a expressão dos estados comportamentais, apontou que: a) taxas de estados ativos do grupo IS eram significativamente menores quando comparadas às dos grupos DI ( $p<0,021)$, FF $(p<0,004)$ e FFE $(p<0,001)$ e GC ( $<<0,001)$; enquanto que taxa desse mesmo estado comportamental para o grupo GC foi significativamente maior que a dos grupos DI ( $p<0,001), F F(p<0,001)$. Finalmente, a taxa de estados ativos foi significativamente maior para FFE quando comparada a DI $(p<0,007)$ e FF $(p<0,001)$; b) a taxa comportamental de estados inativos foi significativamente maior para FF em relação aos grupos DI ( $\mathrm{p}<0,005)$, FFE ( $p<0,001), \mathrm{GC}(\mathrm{p}<0,001)$; $\mathrm{c})$ por fim, a taxa comportamental de estados sociais para IS foi significativamente maior em relação aos grupos FF ( $p<0,001)$, FFE ( $p<0,001)$ e GC $(p<0,001)$.

Enquanto que em relação às diferenças dos grupos quanto a sua expressão de eventos comportamentais o teste Tuckey HSD apontou que: a) a taxa de eventos agonísticos do grupo GC foi significativamente maior que a dos grupos $\mathrm{FF}(\mathrm{p}<0,003)$, FFE ( $p<0,004)$, IS $(p<0,016) ;$ b) a taxa de eventos ativos exploratórios foi significativamente maior para GC em relação a DI ( $p<0,001), \mathrm{FF}(\mathrm{p}<0,001), \mathrm{FFE}(\mathrm{p}<$ $0,001)$, IS ( $<<0,001)$, enquanto que a referida taxa do grupo FF foi significativamente menor em relação aos grupos FFE ( $p<0,047)$.

Para uma compreensão mais geral das atividades comportamentais foi analisada a taxa de comportamentos superficiais com auxílio do teste Kruskal Wallis. 
Primeiramente, para avaliar a taxa de comportamentos superficiais entraram nas análises apenas os grupos sociais que tinham registro de tempo mínimo $\geq 10$ minutos (251 grupos sociais). Comparamos os dois blocos de meses da estação reprodutiva e verificou-se que a taxa mediana de comportamentos superficiais foi duas vezes superior (valor de $\mathrm{p}<0,003$ ) em agosto/setembro quando comparada a outubro/novembro (ver Figura 7, Tabela 7).

Figura 7. Taxas de comportamentos superficiais ou aéreos por blocos de meses da estação reprodutiva.

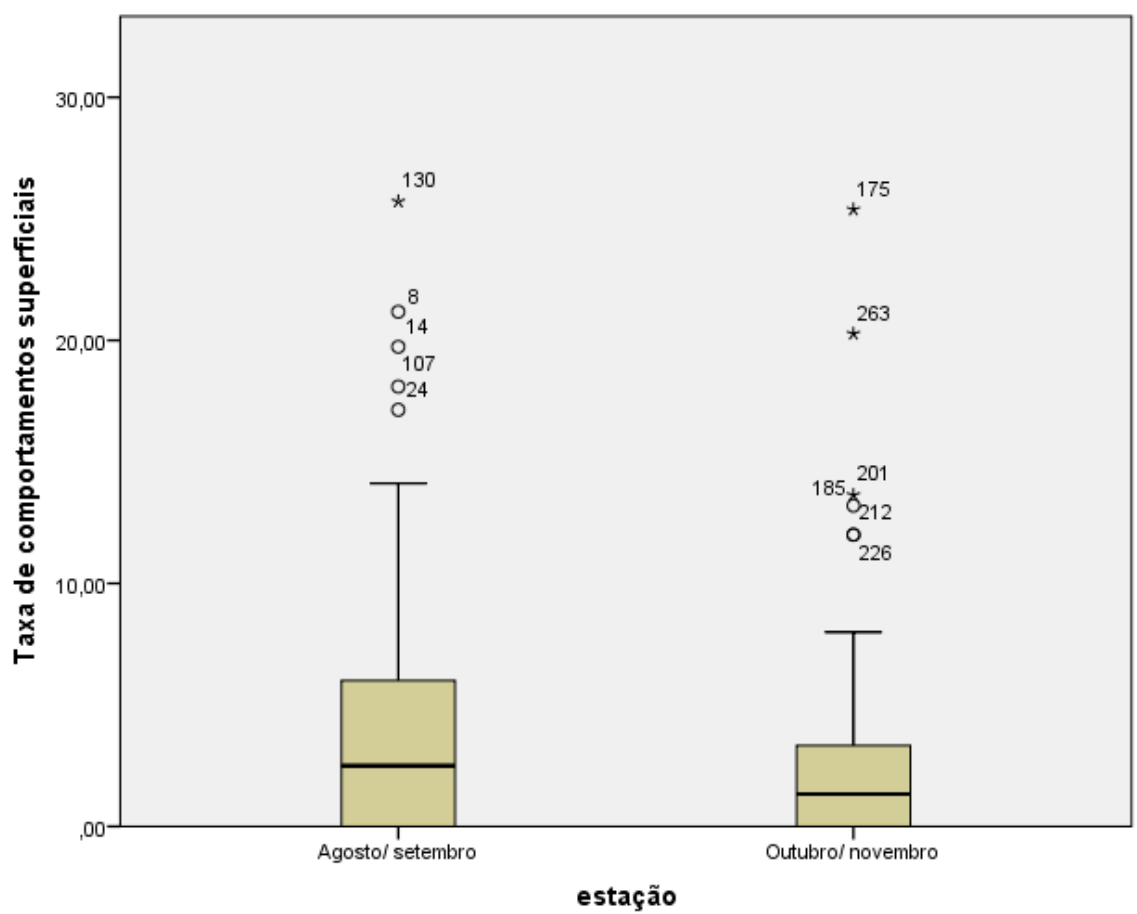

Nota: Teste Kruskal Wallis valor de $\mathrm{p}<0,003$. Símbolos: o - outliers, * - casos extremos (identificados pelo número do etograma)

Tabela 7. Taxas de comportamentos superficiais ou aéreos por bloco de meses da estação.

\begin{tabular}{lccccccc}
\hline Estação & $\begin{array}{c}\text { Freq. } \\
\text { Grupos } \\
\text { sociais }\end{array}$ & Mínimo & $\begin{array}{c}\text { Percentil } \\
25\end{array}$ & Mediana & Média & $\begin{array}{c}\text { Percentil } \\
75\end{array}$ & Máximo \\
\hline Agosto/setembro & 152 & 0 & 0 & 2,5 & 5,2 & 6 & 125,5 \\
Outubro/novembro & 99 & 0 & 0 & 1,3 & 3 & 3,5 & 47,4 \\
\hline
\end{tabular}

Nota: Teste Kruskal Wallis valor de $\mathrm{p}<0,003$. 
Ao avaliar a taxa de comportamentos superficiais por grupo social o teste Kruskal Wallis apontou diferença significativa (ver Figura 8, Tabela 8). O número de amostras foi pequeno, entretanto, e não foi possível encontrar relação significativa para as taxas de comportamento superficial intra-grupo social para os diferentes momentos da estação.

Figura 8. Taxas de comportamentos superficiais ou aéreos por grupo social.

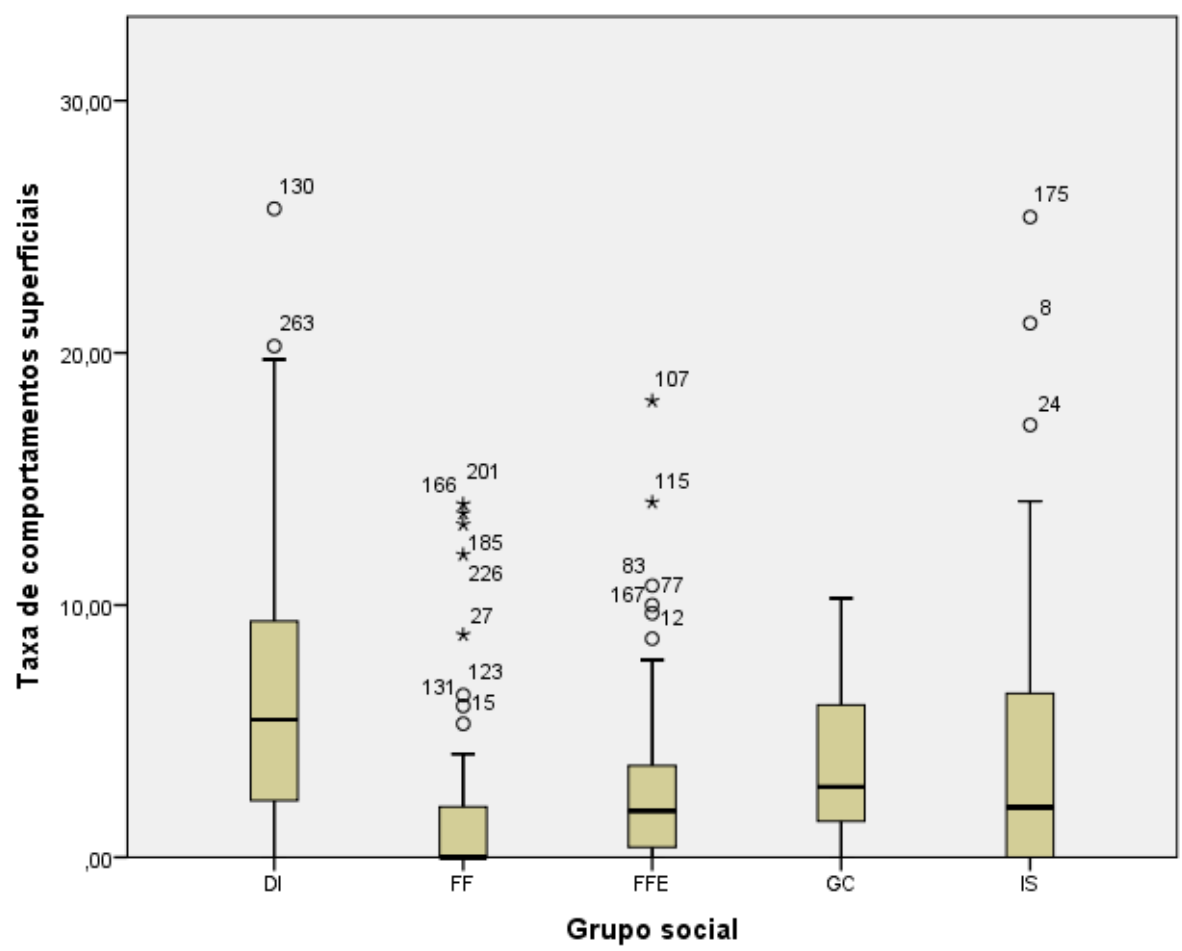

Teste Kruskal Wallis valor de $\mathrm{p}<0,001$.

Tabela 8. Taxas de comportamentos superficiais ou aéreos por grupo social

\begin{tabular}{cccccccc}
\hline $\begin{array}{c}\text { Grupo } \\
\text { social }\end{array}$ & Freq. & Mínimo & $\begin{array}{c}\text { Percentil } \\
25\end{array}$ & Mediana & Média & $\begin{array}{c}\text { Percentil } \\
75\end{array}$ & Máximo \\
\hline DI & 31 & 0 & 2 & 5,5 & 6,7 & 10,7 & 25,7 \\
FF & 62 & 0 & 0 & 0 & 2,5 & 2 & 40 \\
FFE & 84 & 0 & 0,4 & 1,8 & 2,8 & 3,6 & 18,1 \\
GC & 42 & 0 & 1,4 & 2,8 & 4,4 & 6 & 42,9 \\
IS & 32 & 0 & 0 & 2 & 9,5 & 6,5 & 125,5 \\
& & & & & & & \\
\hline
\end{tabular}

Nota: Teste Kruskal Wallis valor de $\mathrm{p}<0,001$. 
Ao compararmos grupos com e sem filhote, foi possível observar diferenças significativas nas taxas de comportamentos superficiais dos adultos. Grupos com filhote apresentam taxas significativamente menores do que os grupos sem filhote, $p<0,001$ (ver Figura 9, Tabela 9).

Figura 9. Taxas de comportamentos superficiais ou aéreos conforme a presença de filhotes.

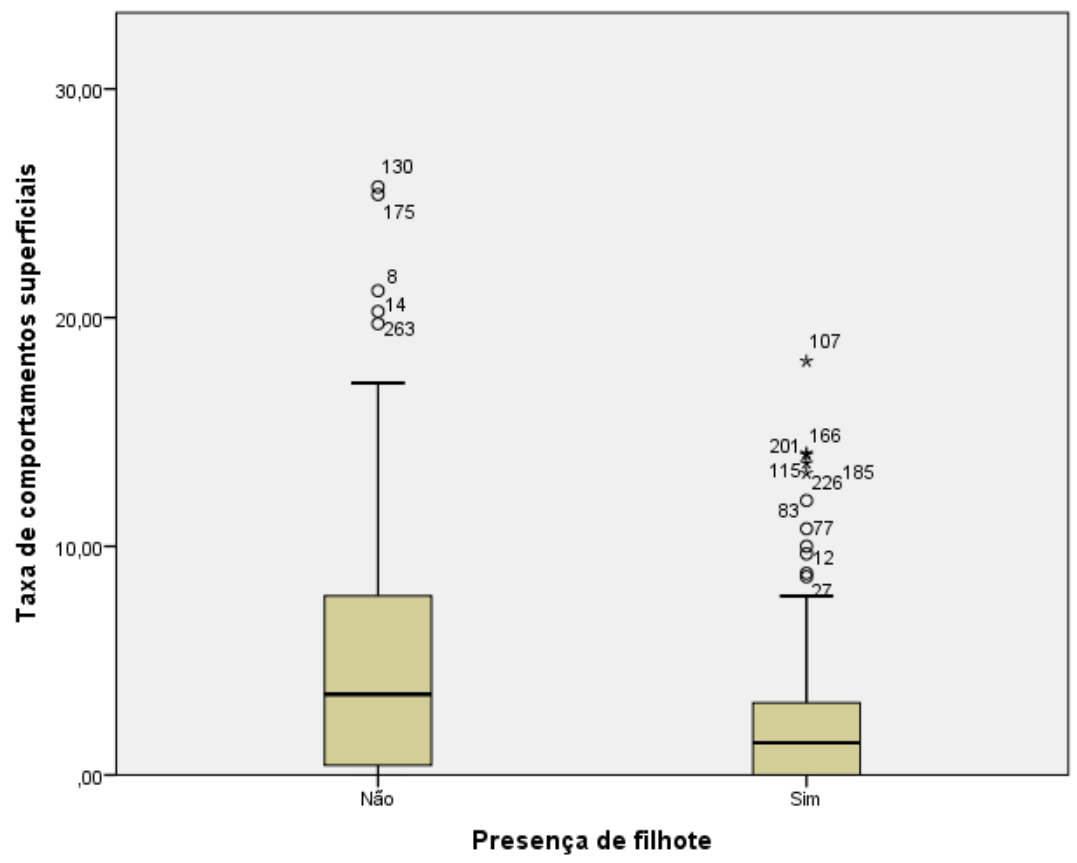

Teste Kruskal Wallis valor de $\mathrm{p}<0,001$.

Tabela 9. Taxas de comportamentos superficiais ou aéreos conforme a presença de filhotes

\begin{tabular}{cccccccc}
\hline Grupos & Freq. & Mín. & $\begin{array}{c}\text { Percentil } \\
25\end{array}$ & Mediana & Média & $\begin{array}{c}\text { Percentil } \\
75\end{array}$ & Máx. \\
\hline Sem filhotes & 87 & 0 & 0 & 3,5 & 7,5 & 8 & 125,5 \\
Com filhotes & 164 & 0 & 0 & 1,4 & 2,6 & 3,2 & 40 \\
\hline
\end{tabular}

Nota: Teste Kruskal Wallis valor de $\mathrm{p}<0,001$.

Para avaliar a influência da quantidade de número de adultos no GC sob as taxas de comportamentos superficiais ou aéreos, foi necessário compor três grupos que agrupavam diferentes quantidades de adultos observados juntos num mesmo GC, 
separando então $\mathrm{GC}(\mathrm{s})$ com até 4 animais, até 6 animais e com até 12 animais, como mostra a tabela 10 .

Não houve diferença significativa entre as taxas de comportamento superficial ou aéreo entre as categorias de números de indivíduos, $\mathrm{p}=0,88$ (Tabela 10).

Tabela 10. Taxas de comportamentos superficiais ou aéreos em três diferentes composições de número de indivíduos em Grupos Competitivos (GC).

\begin{tabular}{cccccccc}
\hline $\begin{array}{c}\text { Número de } \\
\text { indivíduos }\end{array}$ & Freq. Mínimo & $\begin{array}{c}\text { Percentil } \\
25\end{array}$ & Mediana & Média & $\begin{array}{c}\text { Percentil } \\
75\end{array}$ & Máximo \\
\hline $3-4$ & 21 & 0 & 1,3 & 2,8 & 5,1 & 5 & 42,9 \\
$5-6$ & 12 & 0 & 1,5 & 3,4 & 4 & 6,5 & 8,8 \\
$7-12$ & 9 & 0,9 & 1,9 & 2,3 & 3,3 & 4,1 & 7,7 \\
\hline
\end{tabular}

Nota: Teste Kruskal Wallis valor de $\mathrm{p}=0,886$.

Ao comparar as taxas de comportamento superficial ou aéreo dos Grupos competitivos com e sem filhote, foi observada diferença significativa, $p<0,02$, como pode ser visto na Figura 10, Tabela 11.

Figura 10. Taxas de comportamentos superficiais o aéreos do Grupo Competitivo (GC) conforme a presença de filhotes.

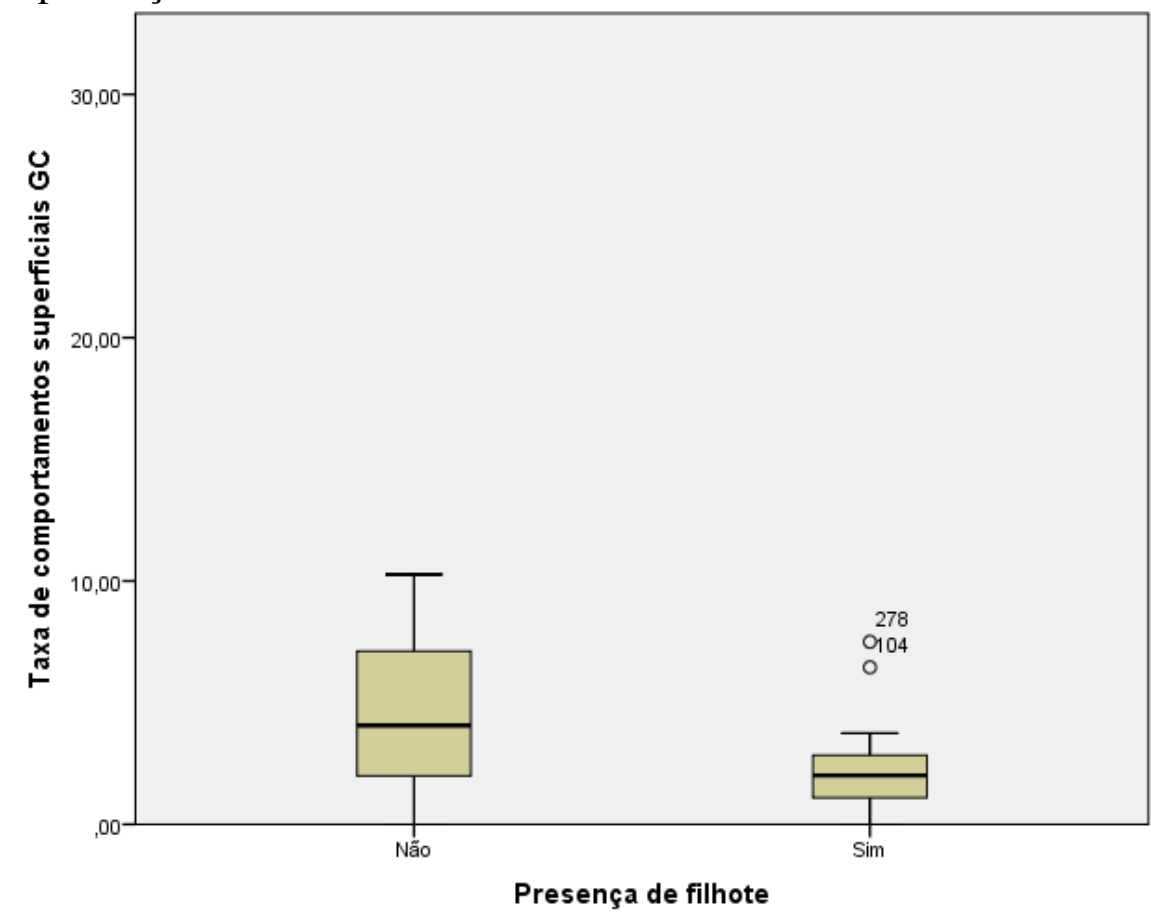


Tabela 11. Taxas de comportamentos superficiais ou aéreos nos Grupos Competitivos (GC) conforme a presença ou não de filhotes

\begin{tabular}{cccccccc}
\hline $\begin{array}{c}\text { Presença de } \\
\text { filhotes }\end{array}$ & Freq. & Mínimo & $\begin{array}{c}\text { Percentil } \\
25\end{array}$ & Mediana & Média & $\begin{array}{c}\text { Percentil } \\
75\end{array}$ & Máximo \\
\hline Não & 24 & 0 & 2 & 4,1 & 5,9 & 7,1 & 42,9 \\
Sim & 18 & 0 & 1,1 & 2 & 2,4 & 2,8 & 7,5 \\
\hline
\end{tabular}

Nota: Teste Kruskal Wallis valor de $\mathrm{p}=0,024$.

\section{Níveis do hormônio do estresse cortisol}

De agosto a novembro de 2014 foram coletadas 37 amostras de borrifo para análise dos níveis de cortisol.

Os grupos sociais com maior número de amostras foram os grupos competitivos com 21 amostras, seguidos por grupos de fêmea com filhote acompanhado por escorte com 10 amostras, grupos de fêmea com filhote com 4 amostras, grupos de dois indivíduos com 1 amostra e grupos de indivíduo solitário com 1 amostra.

Por dificuldades metodológicas devido à alta abundância de indivíduos na área, não foi possível identificar os indivíduos que forneceram as amostras, em alguns grupos sociais. Entretanto a identificação de gênero foi possível em 13 amostras de fêmeas, 4 de escortes e 20 de indivíduos sem identificação.

Considerando, portanto, apenas os animais que tiveram amostras de borrifos coletados foi possível observar, primeiro, que os níveis de cortisol não sofreram alterações significativas entre os diferentes blocos de meses da estação reprodutiva $p=$ 0,684 conforme análise Kruskal Wallis.

Em seguida, observou-se também que não houve correlação significativa entre os níveis de cortisol e as taxas de comportamento aéreo, conforme análise Pearson $(R=$ $-0,022, p=0,899)$. Quando, contudo, foi avaliada a correlação entre cada um dos estados e eventos comportamentais com os níveis de cortisol, identificou-se uma significativa correlação negativa entre os comportamentos eventos ativos exploratórios com os níveis 
de cortisol coletados, conforme Pearson $R=-0,408, \mathrm{p}<0,012$. Isto é, quanto maior os níveis do hormônio do estresse (cortisol), menor a taxa dos comportamentos eventos ativos exploratórios.

Ademais, houve diferença significativa entre os níveis de cortisol e o número de adultos dos grupos sociais, $\mathrm{p}=$ 0,016 conforme análise Kruskal Wallis, (ver Figura 11, Tabela 12) e uma correlação negativa significativa entre o número de adultos nos grupos sociais e os níveis de cortisol, conforme análise Pearson $R=-0,442, \mathrm{p}<0,006$ (Figura 12), ou seja, quanto maior o número de indivíduos adultos no grupo, menor o nível de cortisol.

Figura 11. Concentração de cortisol $(\mathrm{Ng} / \mathrm{ml})$ por número de adultos do grupo social.

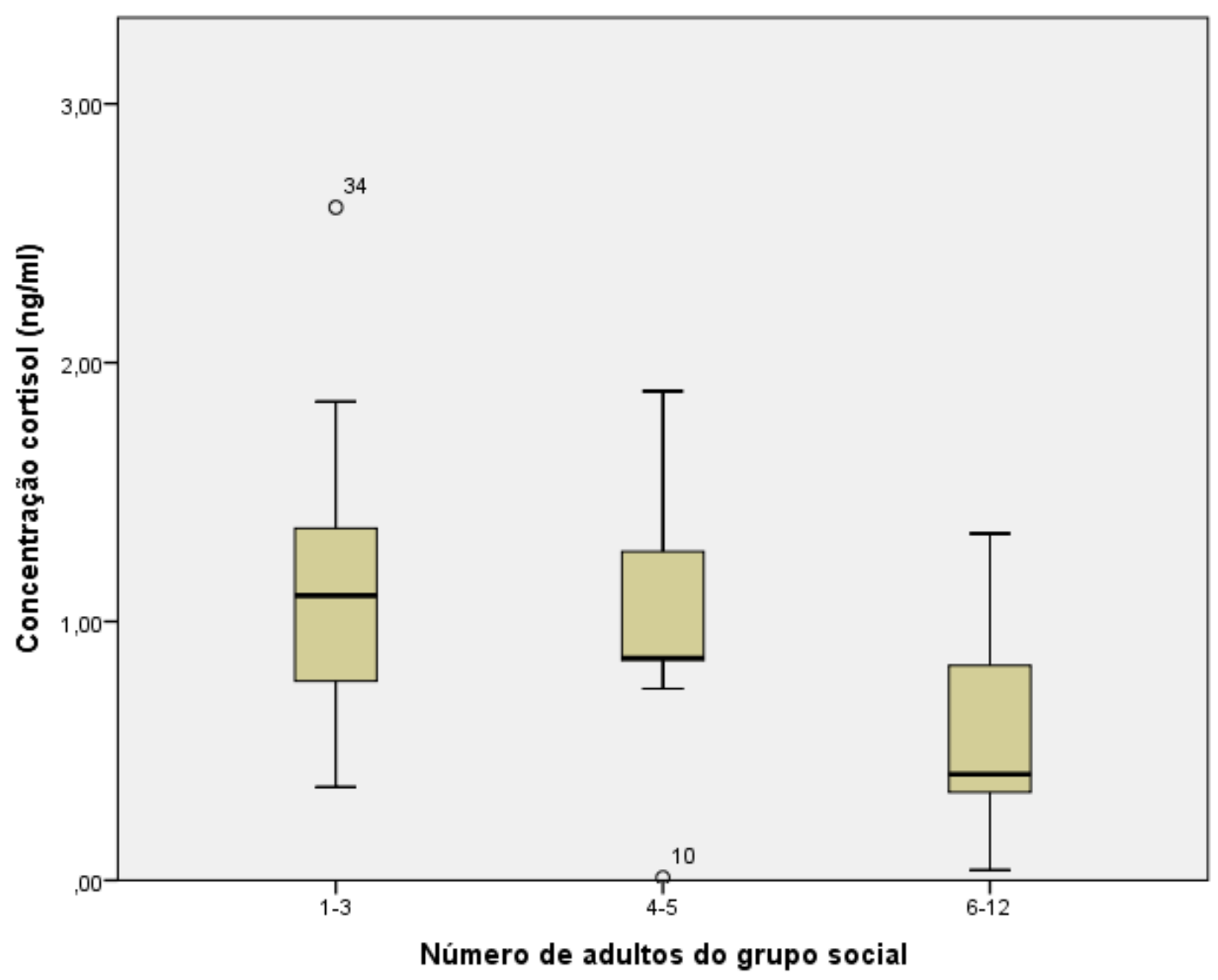


Tabela 12. Concentração de cortisol $(\mathrm{Ng} / \mathrm{ml})$ por número de adultos do grupo social

\begin{tabular}{cccccccc}
\hline $\begin{array}{c}\mathrm{N}^{\circ} \text { de } \\
\text { adultos }\end{array}$ & $\begin{array}{c}\mathrm{N}^{\circ} \text { de } \\
\text { amostras }\end{array}$ & Mínimo & $\begin{array}{c}\text { Percentil } \\
25\end{array}$ & Mediana & Média & $\begin{array}{c}\text { Percentil } \\
75\end{array}$ & Máximo \\
\hline & & & & & & & \\
1 a 3 & 18 & 0,36 & 0,77 & 1,1 & 1,18 & 1,36 & 2,6 \\
4 a 5 & 9 & 0,01 & 0,85 & 0,86 & 0,96 & 1,27 & 1,89 \\
6 a 12 & 10 & 0,04 & 0,34 & 0,41 & 0,55 & 0,83 & 1,34
\end{tabular}

Nota: Teste Kruskal Wallis valor de $\mathrm{p}=0,016$

Figura 12. Correlação entre a concentração de cortisol $(\mathrm{Ng} / \mathrm{ml})$ por número de adultos do grupo social.

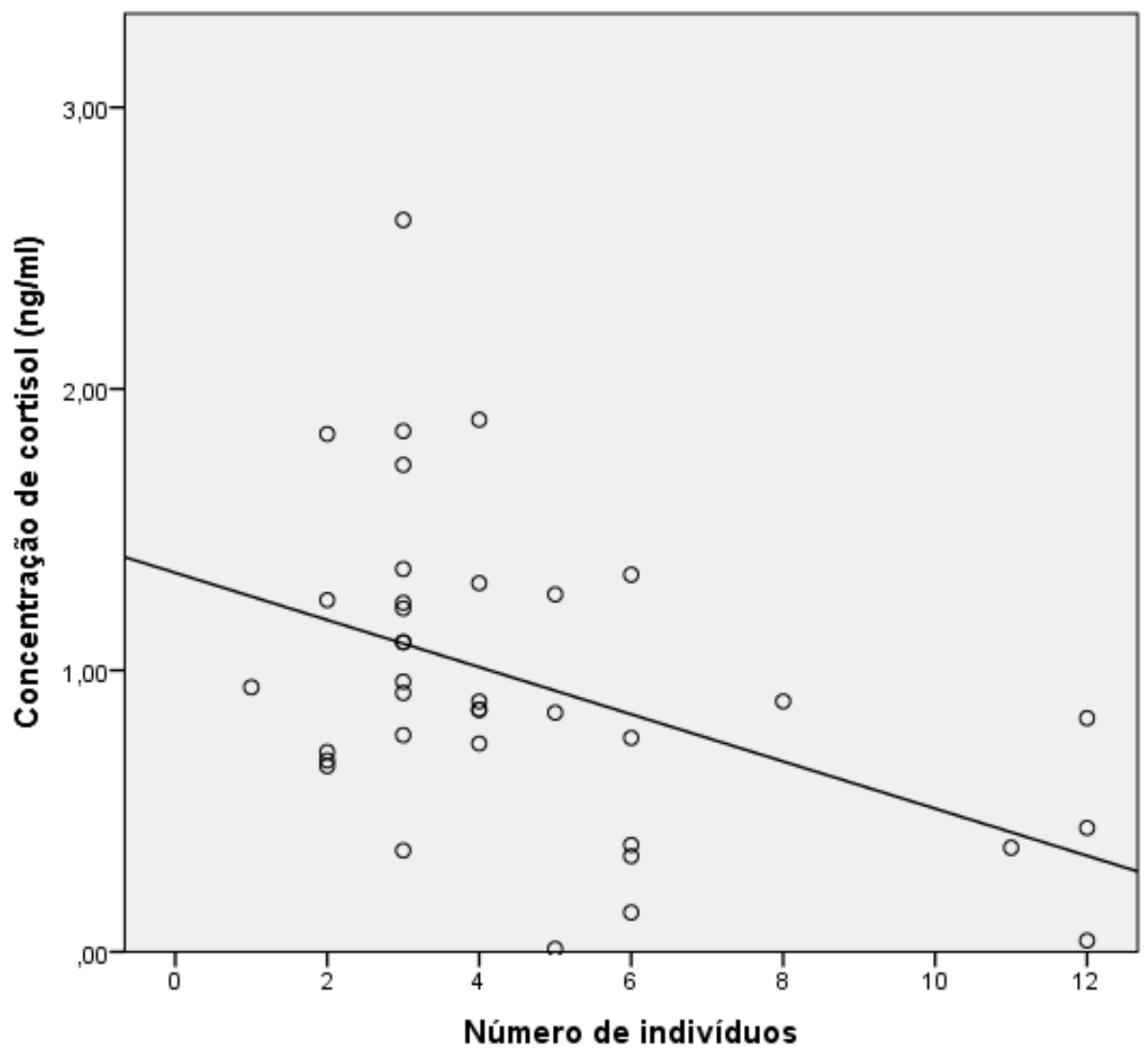

Teste Pearson com correlação é significativa $\mathrm{p}=0,01$

Por outro lado, quando analisados os níveis de cortisol dos grupos sociais considerando a presença do filhote no grupo, foi possível observar que os grupos apresentaram significativamente um nível de concentração de cortisol (hormônio do 
estresse) maior que os grupos que não tinham filhotes, conforme análise Kruskal Wallis, $\mathrm{p}=0,016,($ ver Figura 13, Tabela 13).

Figura 13. Concentração de cortisol ( $\mathrm{Ng} / \mathrm{ml})$ conforme a presença de filhote.

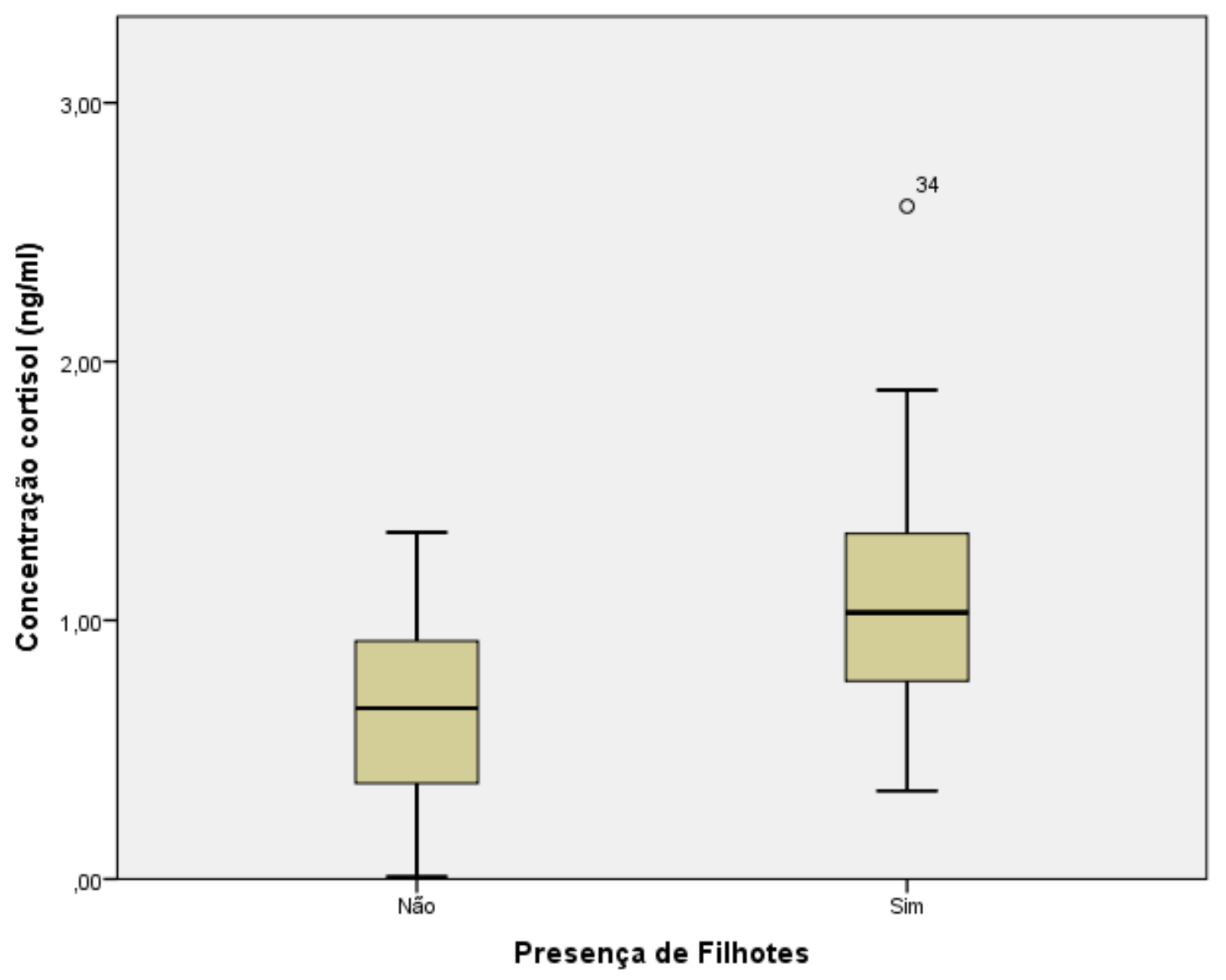

Tabela 13. Concentração de cortisol $(\mathrm{Ng} / \mathrm{ml})$ conforme a presença de filhote no grupo

\begin{tabular}{lccccccc}
\hline \multicolumn{1}{c}{ Grupos } & $\begin{array}{c}\mathrm{N}^{\circ} \text { de } \\
\text { amostras }\end{array}$ & Mínimo & $\begin{array}{c}\text { Percentil } \\
25\end{array}$ & Mediana & Média & $\begin{array}{c}\text { Percentil } \\
75\end{array}$ & Máximo \\
\hline Sem filhotes & 13 & 0,01 & 0,37 & 0,66 & 0,63 & 0,92 & 1,34 \\
Com filhotes & 24 & 0,34 & 0,77 & 1,03 & 1,14 & 1,34 & 2,60 \\
\hline
\end{tabular}




\section{Discussão}

O presente trabalho verificou que a frequência de filhotes é significativamente menor para o mês de agosto em relação a setembro, a outubro e a novembro, e significativamente maior para o mês de outubro em relação aos meses de agosto e de setembro, corroborando a descrição de vários pesquisadores de que, a partir do meio para o fim da estação reprodutiva - precisamente a partir de setembro, englobando os meses de outubro e de novembro - observa-se um período onde ocorre um aumento da presença de grupos sociais com filhote (Martins et al., 2001; Morete et al., 2003; Morete, 2007). Jubartes registradas na costa do Equador surgem mais significativamente na companhia de filhotes a partir do fim de agosto (Felix \& Haase, 2001).

Apesar deste estudo não ter encontrado diferença significativa entre a distribuição geográfica dos avistamentos totais dos grupos sociais entre áreas próximas aos Recifes Costeiros e à área do Canal dos Abrolhos, os dados identificaram uma maior frequência de avistamentos de grupos sociais próximo ao Canal de Abrolhos em agosto em relação a outubro e a novembro, em setembro em relação a novembro; enquanto que nos Recifes Costeiros ocorreu uma frequência de avistamentos de grupos sociais maior em novembro do que em agosto; e setembro e em outubro uma frequência de avistamentos maior do em agosto, $\mathrm{p}<0,001$. Esta situação pode estar associada ao fato já registrado por trabalhos anteriores (Lunardi et al., 2008; Martins et al., 2001; Morete, 2007; Ersts \& Rosenbaum, 2003) que descrevem preferências de uso de habitat em baixas latitudes associadas à organização social, onde mães e filhotes preferem águas rasas e mais próximas à costa, provavelmente para evitar predação por tubarões e perseguição dos machos, visto que $64 \%$ do total de avistamentos de nossas amostras eram grupos sociais com filhotes. Além disso, a distribuição de FF pode ser influenciada pela dinâmica da água, pelas áreas protegidas de ventos que atenuam a dinâmica de movimento do mar. Águas calmas podem favorecer a amamentação e potencialmente permitem que o filhote mantenha-se próximo à mãe com um menor esforço (Martins et al., 2001). Uma vez que as fêmeas com filhote são as ultimas a deixarem as áreas de reprodução, espera-se que elas sejam encontradas com maior frequência no fim da temporada em águas abrigadas. 
Ao analisarmos as taxas de comportamento, tanto na ANOVA quanto MANOVA, a categoria comportamental estado ativo, que envolvem Natação e Milling, se apresentou significativamente diferente entre os grupos, $\mathrm{p}<0.001$, com o GC com a maior taxa desse estado, conforme teste pos-hoc. Por outro lado, o estado inativo, que envolve o comportamento de Repouso, foi significativamente diferente entre os grupos, $\mathrm{p}<0,001$, com a maior taxa significativa para o grupo FF, conforme teste pos-hoc. De forma que podemos supor que essas situações estão associadas às necessidades primarias de cada grupo. O grupo competitivo está engajado em uma busca pela fêmea no ambiente marinho por meio dos comportamentos Natação e Milling, gastando assim muita energia, para então depois expressar outros comportamentos e efetivar o sucesso reprodutivo; enquanto que a fêmea com filhote possui uma demanda energética de gasto relacionado à lactação e cuidado parental, exigindo uma expressão maior do estado comportamental inativo, ou seja, comportamento de repouso. Em convergência a esse argumento, Jones (2010), descreve que fêmeas com filhote no Havaí passam mais tempo em estados inativos de repouso do que em estados ativos, quando comparadas a grupos de fêmeas que estão acompanhadas de filhote e escorte.

Ao analisarmos os eventos comportamentais, tanto a ANOVA quanto MANOVA apontaram diferenças entre os grupos em relação às categorias eventos ativos exploratórios, $\mathrm{p}<0,001$, com o GC apresentando a maior taxa dessa categoria comportamental, conforme teste pos-hoc. A ANOVA ainda apontou diferença entre os grupos em relação à categoria comportamental eventos agonísticos, $\mathrm{p}<0,001$, com o teste pos-hoc, apontando o GC com a maior taxa dessa categoria comportamental. Por outro lado, as menores taxas significativas de categoria de eventos ativos exploratório foram conforme teste pos-hoc, expressadas respectivamente pelos grupos FFE e FF. Estes dados estão de acordo com outras pesquisas que apontam os GC apresentando comumente comportamentos agressivos, (Baker \& Herman, 1984; Tyack \& Whitehead, 1983) e as fêmeas com filhote comumente apresentando comportamentos de repouso e de cuidado parental (Jones 2010).

O número de indivíduos num grupo competitivo (GC) com até 4 animais, até 6 animais ou até com 12 animais, no entanto, não apresentou diferença significativa entre as taxas de comportamento superficial ou aéreo, isto é, em nenhuma dessas condições essa categoria de comportamento aumentou ou diminuiu, conforme análise Kruskal Wallis, $\mathrm{p}=0,88$. Porém, quando avaliamos a fisiologia do estresse através dos níveis do 
hormônio cortisol em correlação a cada um dos estados e eventos comportamentais, identificamos uma significativa correlação negativa entre os comportamentos eventos ativos exploratórios com os níveis de cortisol coletados, conforme Pearson $R=-0,408$, $\mathrm{p}<0,012$. Ou seja, quanto maior foram os níveis do hormônio do estresse (cortisol) coletado, menores foram as taxas observadas dos comportamentos eventos ativos exploratórios.

Houve diferença significativa entre os níveis de cortisol e o número de adultos dos grupos sociais, p<0,016 conforme análise Kruskal Wallis, com uma correlação negativa significativa entre o número de adultos nos grupos sociais e os níveis de cortisol, conforme análise Pearson $R=-0,442, \mathrm{p}<0,001$, isto é, quanto maior o número de indivíduos adultos no grupo, menor o nível de cortisol. Isto possivelmente sugere que os grupos sociais, e provavelmente os GC, por se tratarem de grupos com números elevados de machos, apresentariam um menor nível de cortisol por fazerem parte se um sistema poligínico de dominância dos machos. Em um contexto em que machos não defendem as fêmeas diretamente ou recursos essenciais para as fêmeas no contexto da reprodução, eles estabeleceriam entre eles sua posição relativa de dominância sendo que a fêmea escolheria o macho por seu status (Elen \& Oring, 1977). Os pequenos grupos de machos com comportamento agressivo semelhante ao de grupos competitivos podem estar relacionados a um estabelecimento de dominância que ajudaria a mediar interações futuras entre indivíduos conhecidos (Clapham et al., 1992), o que pode influenciar nos níveis de cortisol. Outro ponto que parece estar relacionado ao menor nível de cortisol para grupos maiores estaria associado ao argumento de Elen \& Origin (1977) de que machos de status inferior podem investir em estratégias alternativas crípticas ou satélite em áreas de display para obter acesso a fêmeas: as chances são maiores do que se evitassem áreas com muitos machos.

Em grupos competitivos, os machos estabelecem relações de dominância para o acesso a fêmeas. Clapham (1996) descreveu o sistema de reprodução das Jubartes num modelo de "floating lek", no qual os machos se exibem fisicamente, cantam para atrair as fêmeas e envolvem-se em disputas físicas pela posição de escorte principal. Em tal contexto, a expressão de altas taxas de comportamentos ativos exploratórios e agonísticos são esperados em um primeiro momento, quando os grupos se formam, ou quando há afiliação de um novo indivíduo ao grupo. Após certo tempo, as relações de dominância seriam estabelecidas e comportamentos agonísticos e agressivos 
diminuiriam. Clapham (1992) argumenta que grupos competitivos podem estabelecer relações de dominância de forma rápida. Outro fator a ser levado em consideração é que machos de jubarte podem relacionar-se socialmente de forma cooperativa para assegurar o acesso à fêmea. Isso pode levá-los a um nível de estresse menor para esses escortes secundários. É possível sugerir que o reconhecimento de dominância entre indivíduos, a cooperação entre escortes secundários para ter acesso à fêmea, as estratégias crípticas ou satélites diminuem situações fisiológicas de estresse, abaixando o nível de cortisol, apesar dos indivíduos, em algum momento vivenciarem situações comportamentais de disputa e agressão, nas quais os machos expressam comportamentos de eventos agonísticos e ativos exploratórios.

Finalmente, o cuidado com o filhote em vários momentos neste estudo apresentou indícios de maior custo energético dos adultos. Primeiramente, porque ao compararmos os grupos com e sem filhote através da analise Kruskal Wallis, foi possível observar que grupos com filhote apresentam as taxas comportamentos superficiais ou aéreos significativamente menores que os grupos sem filhote $\mathrm{p}<0,001$. Em segundo lugar, quando analisamos os níveis de cortisol foi possível observar que os grupos que tinham filhotes em sua composição apresentaram significativamente um nível de concentração de cortisol (hormônio do estresse) maior que os grupos que não tinham filhotes, conforme análise Kruskal Wallis, p<0,01. Em terceiro lugar, como já relatado, o comportamento Inativo de Repouso se apresentou como a maior taxa significativa no grupo FF. Em convergência a esses dados, tanto Martins et al., (2001) como Jones (2001) levantam vários aspectos sobre o custo da maternidade nas jubartes como locais de pouca profundidade, com pouco ventos, e com pontos de fuga para evitar predação, além de redução de comportamentos para economia de energia. 


\section{Referências Bibliográficas}

ACEVEDO-WHITEHOUSE, K.; ROCHA-GOSSELIN; GENDRON, D. A novel noninvasive tool for disease surveillance of freeranging whales and its relevance to conservation programs. Animal conservation, v. 13, p.217-225, 2009.

ALCOCK, J. A. evolução dos sistemas de acasalamento. Em: Comportamento Animal uma abordagem evolutiva (Alcock, J.). 9a ed., Editora Artmed, São Paulo, p. 379 - 419, 2011.

ALTMANN, J. Observational study of Behavior: Sampling methods. Behaviour, v. 49, p. 227-265, 1974.

ANDRIOLO, A.; ZERBINI, A.N. Migração de baleias-jubarte: o que falta conhecer? Revista de Etologia, v.9, p. 31-33, 2010.

ATKINSON, S., C. COMBELLES, D. VINCENT, P. NATCHIGALL, J. PAWLOSKI AND M. BREESE. Monitoring of progesterone in captive female false killer whales, Pseudorca crassidens. General and Comparative Endocrinology, v.115, p. 323-332, 1999.

BAKER, C.S. \& HERMAN,L.M. Aggressive behavior between humpback whales (Megaptera novaeangliae) wintering in Hawaiian waters. Canadian Journal of Zoology, v. 62, No 10, p. 1922-1937, 1984.

BAKER, C.S. \& HERMAN,L.M. behavioral responses of summering humpback whales to vessel traffic: experimental and opportunistic observation. NPS-NR-TRS-8901. Report from Kewalo Basin Marine Mammal Laboratory, Honolulu, for the US National Park Service, Anchorage, AK, 1989.

BELL, M.E.; WOOD, C.E.; KELLER-WOOD,M. influence of Reproductive State on Pituitary Activity in the Ewe. Domestic Animal Endocrinology, v. 8, No.2, p. 245-254 1991.

BLAIR, C.; RAVER, C.C. Individual Development and Evolution: Experiential Canalization of Self-Regulation. American Psychological Association, v. 48, No. 3, p. 647-657, 2012.

CANTOR, M.; CACHUBA, T.; FERNANDES, L.; ENGEL, M.H. Behavioural reactions of wintering humpback whales (Megaptera novaeangliae) to biopsy sampling in the western South Atlantic. Journal of the Marine Biological Association of the United Kingdom, p.1-11, 2010.

CHU, K.; NIEUKIRK, S. Dosrsal fin scars as indicator of age, sex, and social status in humpback whale (megaptera novaeangliae). Canadian Journal of Zoology, v.66, p. 416-420, 1988. 
CLAPHAM, P.J. The social and reproductive biology of Humpback Whales: an ecological perspective. Mammal Review, v.26, No1, p. 27-49 1996.

CLAPHAM, J.P.; MEAD, J.G. Mammalian Species Megaptera novaeangliae. American Society Mammalogists, v. 604, p.1-9, 1999.

CLAPHAM, P.; MIKHALEV,Y.; FRANKLIN, W.; PATON,D.; BAKER, C.S.; IVASHCHENKO, Y.V.; BROWNELL, R. JR. Catches of Humpback Whales, Megaptera novaeangliae, by the Soviet Union and Other Nations in the Southern Ocean, 1947-1973. Marine Fisheries Review, v. 71, No.1, p. 39-43, 2009.

CLAPHAM, P.J.; PALSBOLL, P.J.; MATILLA, D.K.; VASQUEZ, O. Composition and dynamics of humpback whale competitive groups in the west indies. Behaviour, v. 122, p. 182-194, 1992.

CRAIG, A.S.; HERMAN, L.M. Sex differences in site fidelity and migration of humpback whales (Megaptera novaeangliae) to the Hawaiian Islands. Canada journal of Zoology v.75, p. 1923-1933, 1997.

CRAIG, A.S.; HERMAN, L.M.; PACK, A.A. Male mate choice and male-male competition coexist in the humpback whale (Megaptera novaeangliae). Canadian Journal of Zoology, v. 80, p.745-755, 2002.

EMLEN, S.T. \& ORING, L.W. Ecology, Sexual Selection, and the Evolution of Mating Systems. Science, v. 197, No. 4300, p. 215-223, 1977.

ENGEL, M. Comportamento reprodutivo da baleia Jubarte (Megaptera novaeangliae) em Abrolhos. Anais de Etologia, v. 14, p. 275-284, 1996.

ERSTS, P.J. \& ROSENBAUM, H.C. Habitat preference reflects social organization of humpback whales (Megaptera novaeangliae) on a wintering ground. Zoological Society of London, v.260, p. 337-345, 2003.

FELIX, F. Assessment of the Level of Surface Activity in Humpback Whales During the Breeding Season. The Latin American Journal of Aquatic Mammals, v. 3,p. 25-36, 2004.

FELIX, F. \& HAASE, B. The humpback whale off The Coast of Ecuador, population parameters and behavior. Revista de Biología Marina y Oceanografía, v. 36, No.1, p. 61-76, 2001.

FLISINSKA-BOJANOWSKA, A.; KOMOSA, M.; GILL, J. Influence of pragnancy on diurnal and seasonal change in cortisol, T3 and T4 levels in the maré blood serum. Comp. Biochem. Fisiol., v. 98A, No. 1, p. 23-30, 1991.

HUNT, K. E., R. M. ROLLAND, S. D. KRAUS AND S. K. WASSER. Analysis of fecal glucocorticoids in the North Atlantic right whale (Eubalaena glacialis). General and Comparative Endocrinology, v. 148, p.260-272, 2006. 
HOGG, C.J.; ROGERS, T.L.; SHORTER, A.; BARTON, K.; MILLER, P.J.O.; NOWACEK, D. Determination of steroid hormones in whale blow: It is possible. Marine Mammal Science, v. 25, No. 3, p.605-618, 2009.

HOGG, C. J., E. R. VICKERS AND T. L. ROGERS. Determination of testosterone in saliva and blow of bottlenose dolphins (Tursiops truncatus) using liquid chromatography-mass spectrometry. Journal of Chromatography, v. 814, p. 339-346, 2005.

INSTITUTO CHICO MENDES DE CONSERVAÇÃO DA BIODIVERSIDADE. Parque Nacional Marinho dos Abrolhos. Disponível em: http://www.icmbio.gov.br/parnaabrolhos/o-que-fazemos.html Acesso em: 05 de Maio de 2015 .

JONES, M.E. Female humpback whale (Megaptera novaeangliae) reproductive class and male-female interactions during the breeding season. Tese (Doutorado em Filosofia) - Antioch University New England, Keene, NH USA. 2010.

KAUFMAN, G.D. \& FORESTELL, P.H. Behavior key Em: Hawaii's Humpback Whales $2^{\text {a }}$ Ed., Pacific Whale Fundation Press, p. 79-89, 1993.

LUNARDI, D.G,; ENGEL, M.H.; MACEDO, R.H.F. Behavior of humpback whales, Megaptera novaeangliae (Cetacea: Balaenopteridae): comparisons between two coastal areas of Brazil. Revista Brasileira de Zoologia, v. 25 No.2, p. 159-164, 2008.

MANN, J. Behavioral Sampling Methods for Cetaceans: A Review and Critique. Society for Marine Mammology, v. 15, No.1, p. 102-122, 1999.

MARTINS, C.C.A.; MORETE, M.E.; ENGEL, M.H.; FREITAS, A.C.; SECCHI,E.R.; KINAS, P.G. Aspects of habitat use patterns of humpback whales in the abrolhos bank, brazil, breeding ground. Memoirs of the Queensland Museum, v.47, No 2, 2001.

MEDRANO, L.; SALAS, I.; DE GUEVARA, P.L.; SALINAS, M.; AGUAYO, A.; JACOBSEN, J.; BAKER, C.S. Sex identification of humpback whales, Megaptera novaeangliae, on the wintering grounds of the Mexican Pacific Ocean. Canadian Journal of Zoology, v. 72, p. 1771-1774, 1994.

MOBLEY, J.R. \& HERMAN,L.M. Transience of social affiliations among Humpback whale (Megaptera novaeangliae) on the Hawaiian wintering grounds. Canadian Journal of Zoology, v.63 p. 762-772, 1985.

MOBERG, G.P. Problems in defining stress in animals. Journal of the American Veterinary Medical Association, v. 191, No.10, 1987.

MORETE, M.E. Caracterização temporal da estrutura de grupos e do comportamento de baleias Jubarte (Megaptera novaeangliae) na área de reprodução do Arquipélago dos Abrolhos (Bahia, Brasil). Tese (Doutorado em Ecologia) - Instituto de Biociências da Universidade de São Paulo, São Paulo. 2007. 
MORETE, M.E., PACE,R.M.; MARTINS, C.C.A.; FREITAS, A.C.; ENGEL,M.H. Indexing seazonal abundance of Humpback Whale around Abrolhos Aechipelago, Bahia, Brazil. Latin American Journal of Aquatic Mammals, v. 2, No. 1, p. 21-28, 2003.

PACHECO, A. S.; SILVA, S.; ALCORTA, B.BALDUCCI, N.; GUIDINO, C.; LLAPAPASCA, M. A.;SANCHEZ-SALAZAR, F. Aerial behavior of humpback whales Megaptera novaeangliae at the southern limit of the southeast Pacific breeding área. Revista de Biología marina y oceanografía, v. 48, No. 1, p. 185-191, 2013.

REEDER, D.M. \& KRAMER, K.M. Stress in Free-Ranging Mammals: Integrating Physiology, Ecology and Natural History. Journal of Mammalogy, v.86, No. 2, p. 225$235,2005$.

RIZZO, L.Y; SCHULTE, D. A review of humpback whales' migration patterns worldwide and their consequences to gene flow. Journal of the Marine Biological Association of the United Kingdom, v. 89, No.5, p. 995-1002, 2009.

ROBECK, T. R., A. L. SCHNEYER, J. F. MCBAIN, L. M. DALTON, M. T. WALSH, N. M. CZEKALA AND D. C. KRAEMER. Analysis of urinary immunoreactive steroid metabolites and gonadotropins for characterization of the estrous cycle, breeding period, and seasonal estrous activity of captive killer whales (Orcinus orca). Zoo Biology, v. 12, p. 173-187, 1993.

SANDS, J. \& CREEL, S. Social dominance, aggression and faecal glucocorticoid levels in a wild population of wolves, Canis lúpus. Animal Behaviour, v. 67, p. 387-396, 2004.

SCHEIDAT, M.; CASTRO, C.; GONZALEZ, J.; WILlIAMS, R. Behavioural responses of humpback whales (Megaptera novaeangliae) to whalewatching boats near Isla de la Plata, Machalilla National Park, Ecuador. J. Cetacean Res. Manage, v.6, No. 1, p. 000-000, 2004.

SETCHELL, J.M.; SMITH, T.; WICKINGS, E.J.; KNAPP, L.A. Sex, Social Behavior, and Secondary sexual traits in a male primate. Hormones and Behavior, v. 58, p. 720 $728,2010$.

SILVA, A.S.; LEÃO, Z.M.A.N.; KIKUCHI, R.K.P.; COSTA, A.B.; SOUZA J.R.B. Sedimentation in the coastal reefs of Abrolhos over the last decades. Continental Shelf Research, v. 70 p. No. 70, p. 159-167, 2013.

SIMÕES, D.G.; MACEDO, R.H.F.; ENGEL, M.H. Turismo de Observação de Cetáceos como Ferramenta no Estudo do Comportamento de Baleias Jubarte (Megaptera Novaeangliae). Revista de Etologia, v.7, p. 3-14, 2005.

STEVICK, P.T.; AGUAYO, A.; ALLEN, J.; AVILA, I.C.; CAPELLA, J.; CASTRO, C.; CHATER, K.; ROSA, L.D.; ENGEL, M.H.; FÉLIX, F.; GONZÁLEZ, L.F., FREITAS, A.; HAASE, B.; LLANOY, M.; LODI, L.; MUNOZ, E.; OLAVARRÍA, C.; SECCHI, E.; SCHEIDAT, M.; SICILIANO, S. Migrations of individually identified humpback whales between the Antarctic Peninsula and South America. J. Cetacean Res. Manage, v.6, No.2, p. 109-113, 2004. 
TYACK, P. \& H.P. WHITEHEAD.. Male competition in large groups of wintering humpback whales. Behaviour v. 83, p.132-154, 1983.

ZERBINI, A.N.; ANDRIOLO, A.; DA ROCHA, J.M.; SIMÕES-LOPES, P.C.; SICILIANO, S.; PIZZOMO, J.L.; WAITE, J.M.; DE MASTER, D.P.; VANBLARICON, G.R. Winter distribution and abundance of humpback whales (Megaptera novaeangliae) off Northeastern Brazil. J.Cetacean Res. Manage, v.6, No.1, p.101-107, 2004. 
APÊNDICE I

\begin{tabular}{|c|c|c|c|c|c|c|}
\hline Data: & Período da Estação: & Profundidade Início: & Número de indivíduos: & & Tipo de grupo: & \\
\hline Horarío Início: & Horário Fim: & Profundidade Fim: & \multicolumn{4}{|c|}{ Distância embarcação-indivíduo: } \\
\hline Ponto do GPS - 1: & 2: & 3: & \multicolumn{2}{|c|}{$4:$} & 5: & \\
\hline \multicolumn{3}{|c|}{ Eventos comportamentais } & \multirow{2}{*}{\multicolumn{3}{|c|}{ Estado Comportamental }} & \multirow{3}{*}{ Observações } \\
\hline \multicolumn{2}{|c|}{ Composição no grupo } & \multirow{2}{*}{ Categoria do evento } & & & & \\
\hline Ator do evento & Receptor do evento & & Categoria do estado & Início do Estado & Fim do Estado & \\
\hline & & & & & & \\
\hline & & & & & & \\
\hline & & & & & & \\
\hline & & & & & & \\
\hline & & & & & & \\
\hline & & & & & & \\
\hline & & & & & & \\
\hline & & & & & & \\
\hline & & & & & & \\
\hline & & & & & & \\
\hline & & & & & & \\
\hline & & & & & & \\
\hline & & & & & & \\
\hline & & & & & & \\
\hline & & & & & & \\
\hline
\end{tabular}




\section{APÊNDICE II}

Carta de Aprovação do Comitê de Ética de Uso Animal

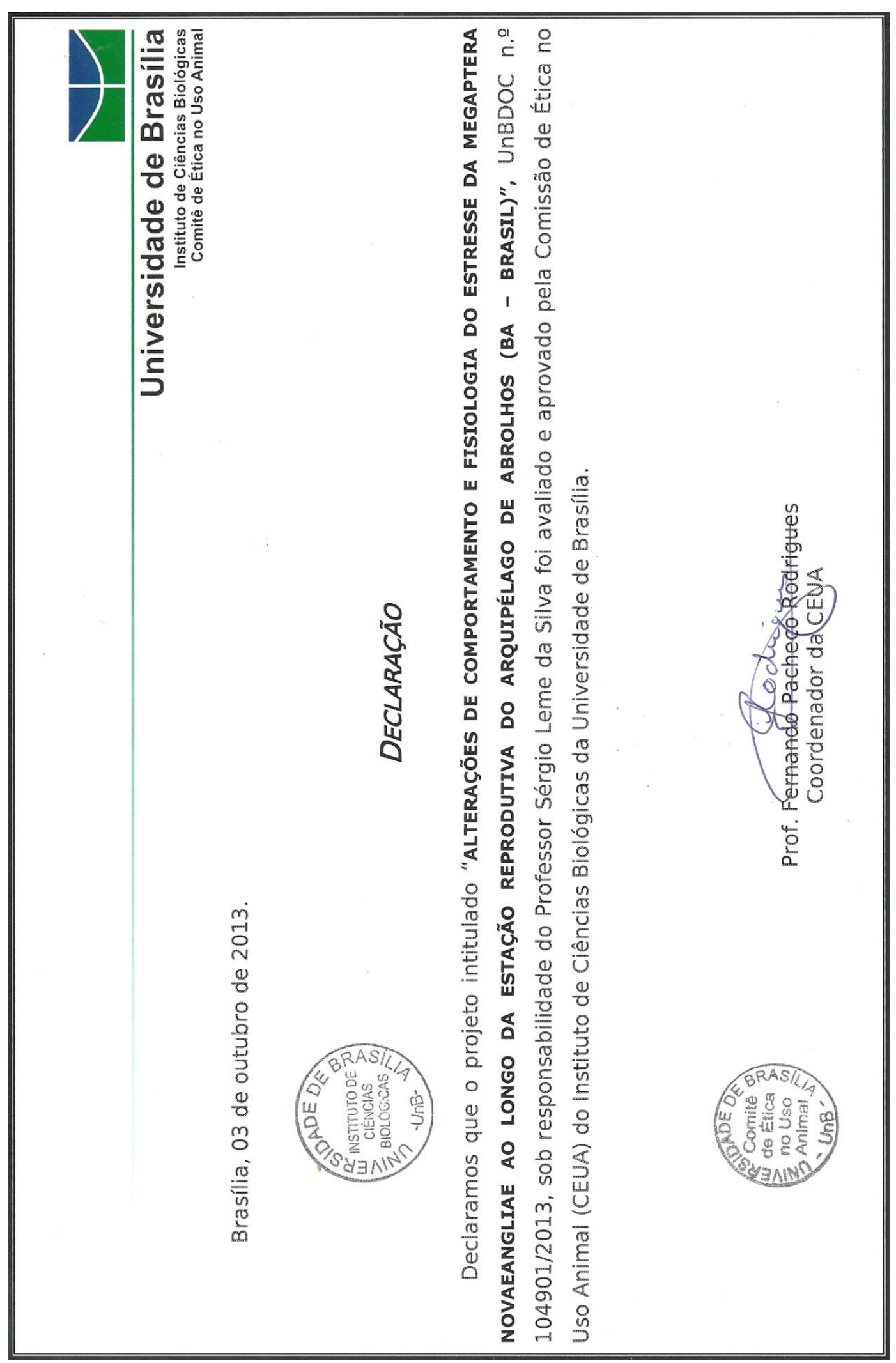




\section{APÊNDICE III}

\section{Fotos dos materiais e métodos}

Figura 2. Placa de acrílico para coleta de borrifo

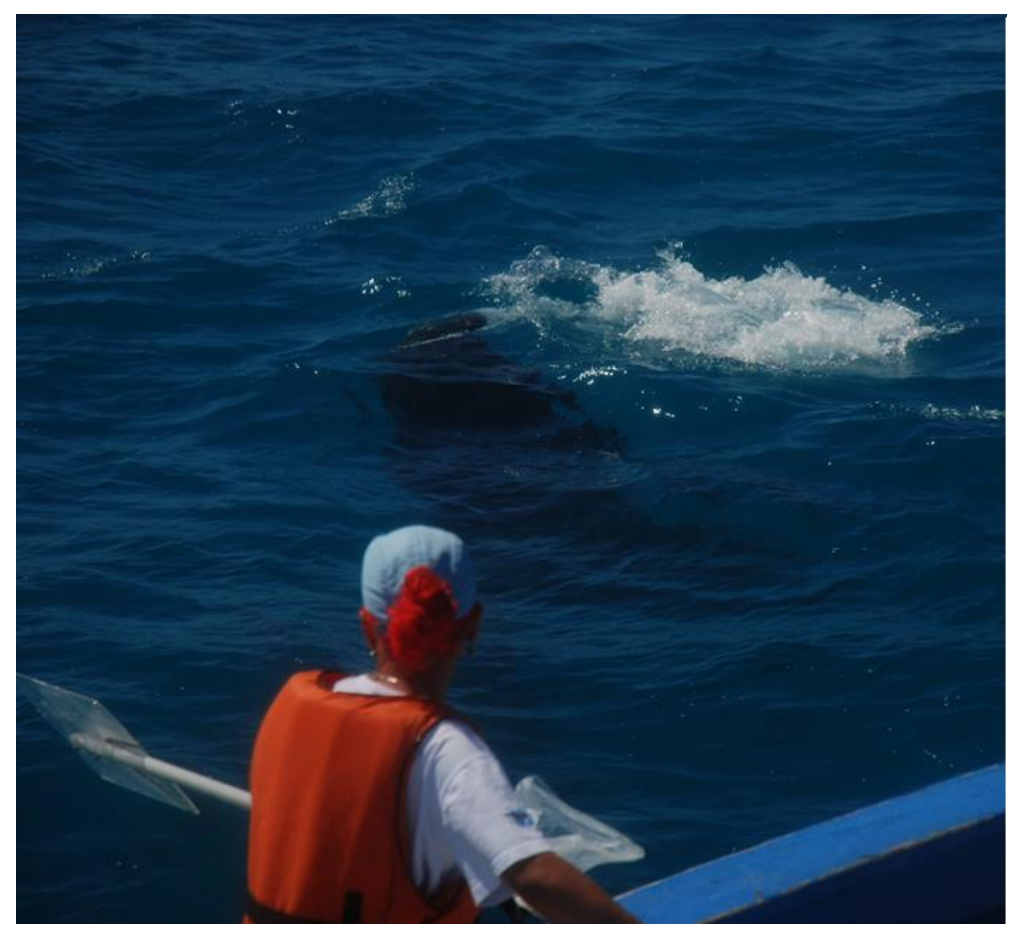

Figura 3. Drone adaptado para coleta de borrifo

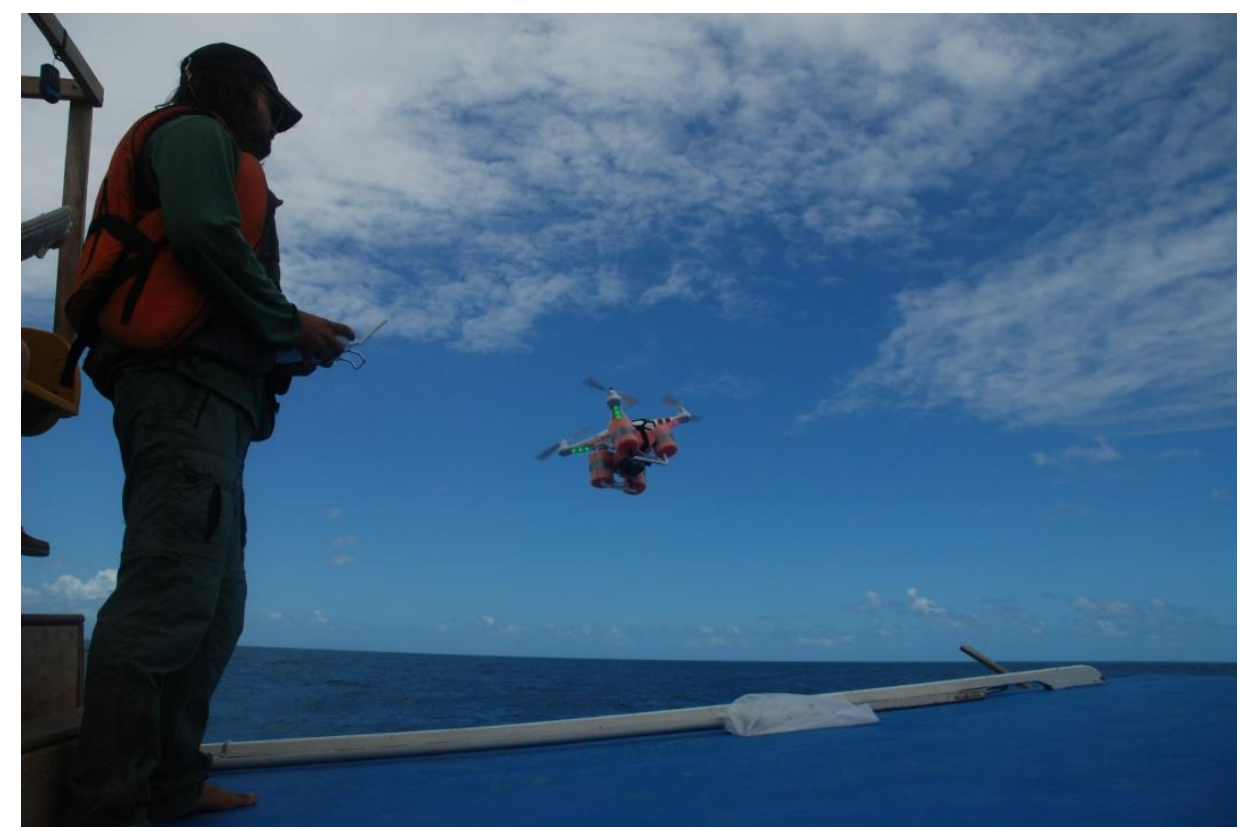

Foto: Marina Guedes 


\section{APÊNDICE IV}

Figura 6. Comportamentos superficiais: (A) batida de caudal, (B) Batida de peitoral, (C)

Salto, (D) Erguimento de cabeça, (E) Spy hop, (F) Mergulho com exposição caudal.

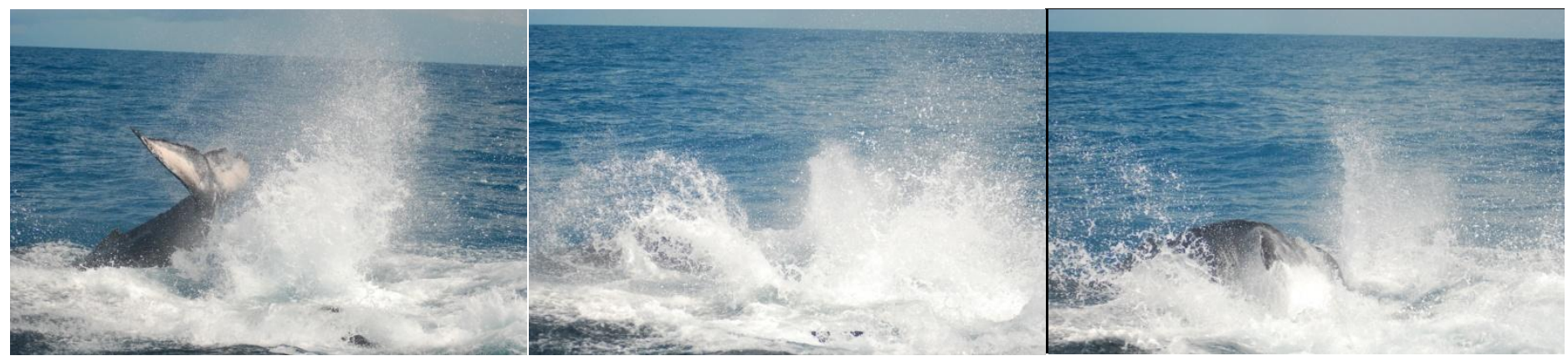

(A) Fotos: Cecília Seminara - IBJ

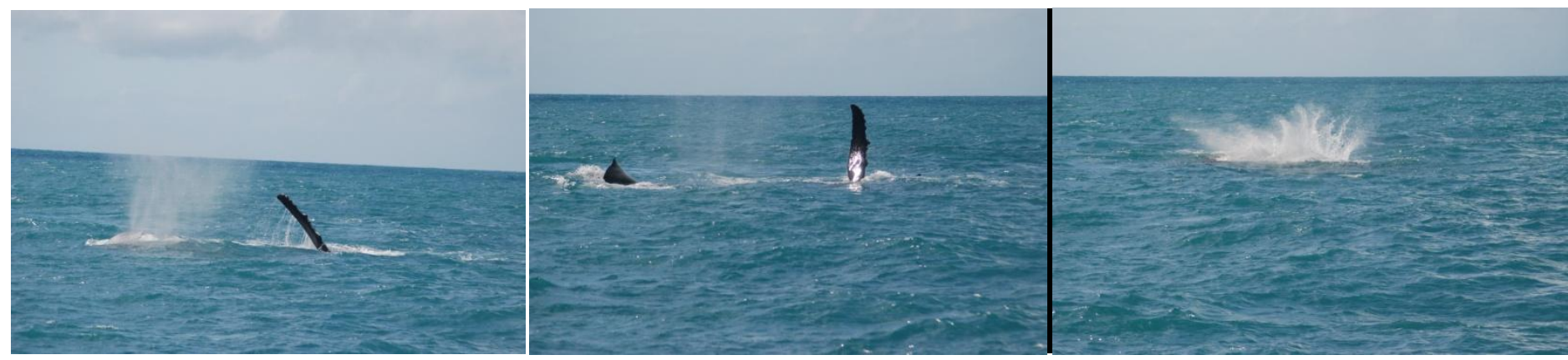

(B) Fotos: Cecília Seminara - IBJ

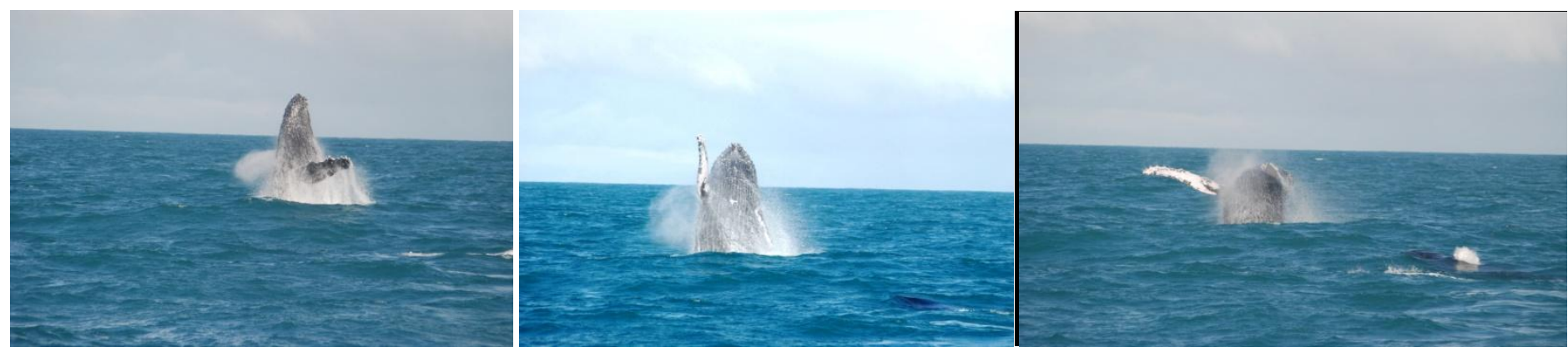

(C) Fotos: Cecília Seminara - IBJ

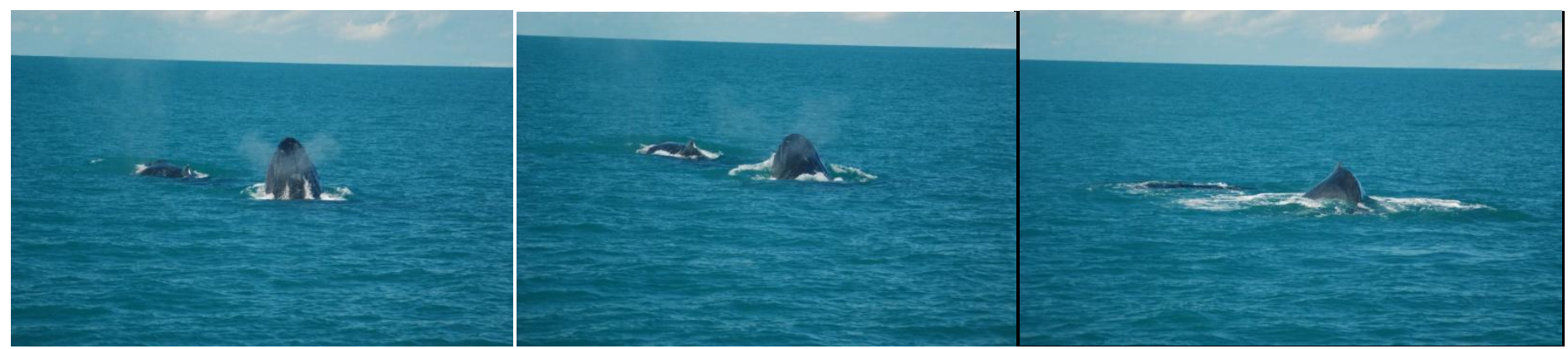

(D) Fotos: Cecília Seminara - IBJ 


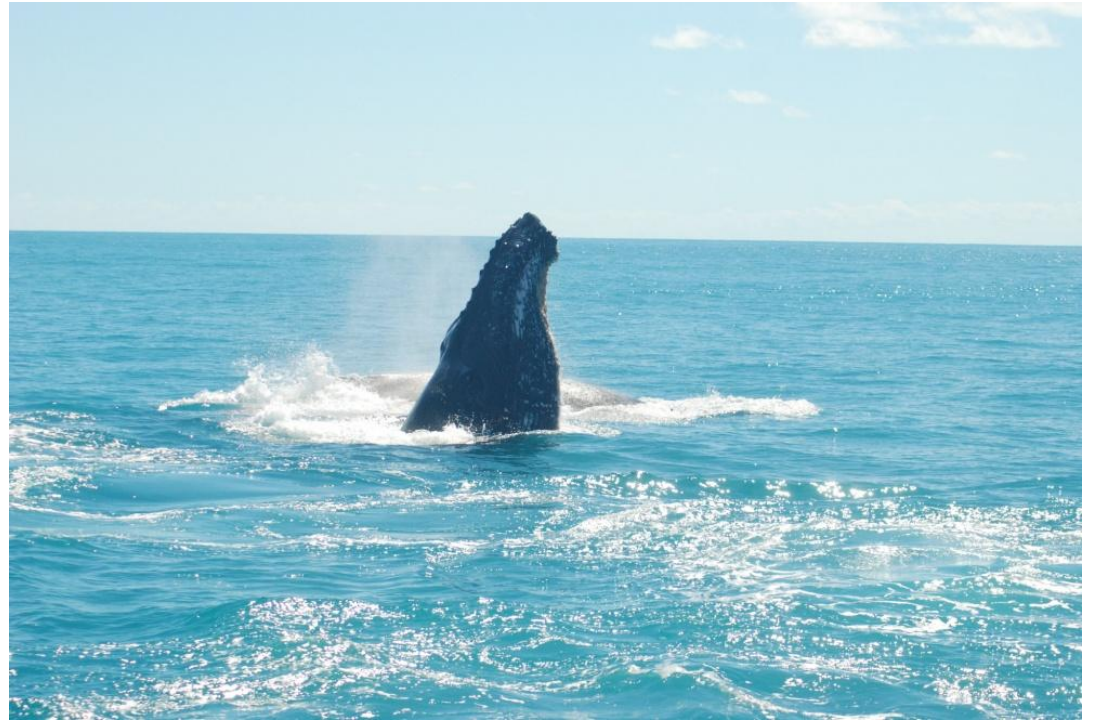

(E) Foto: Cecília Seminara - IBJ

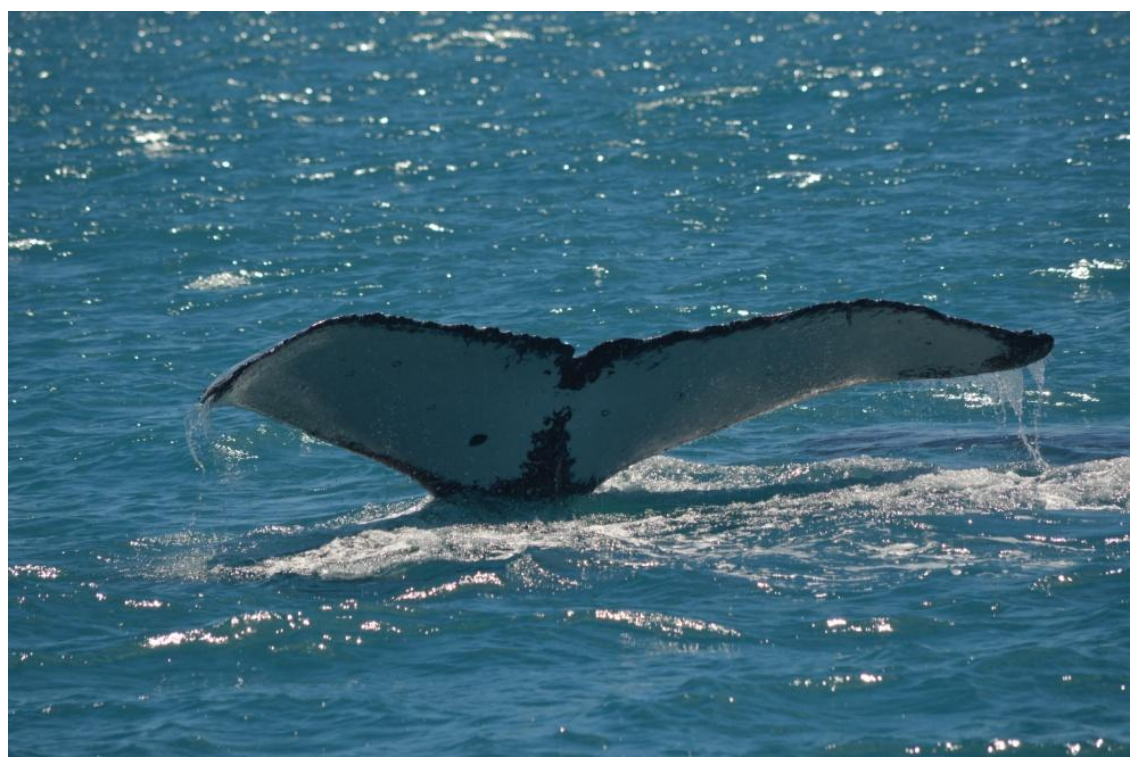

(F) Foto: Milton Marcondes - IBJ 
Figura 7. Fotos de comportamentos observados com drone: (A) Frenagem com mudança de direção, (B) Cabeçada e exalação de bolhas.

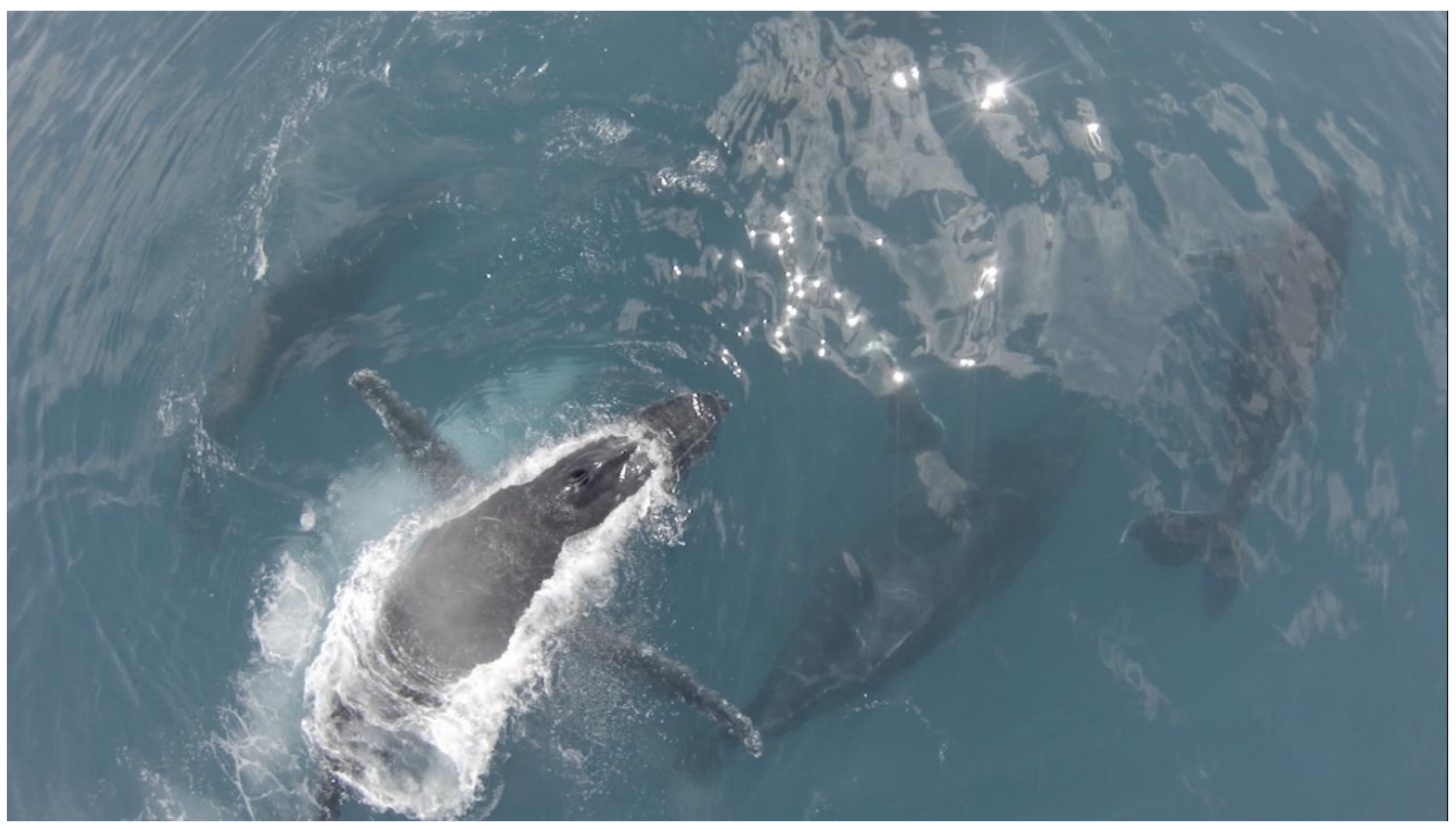

(A)

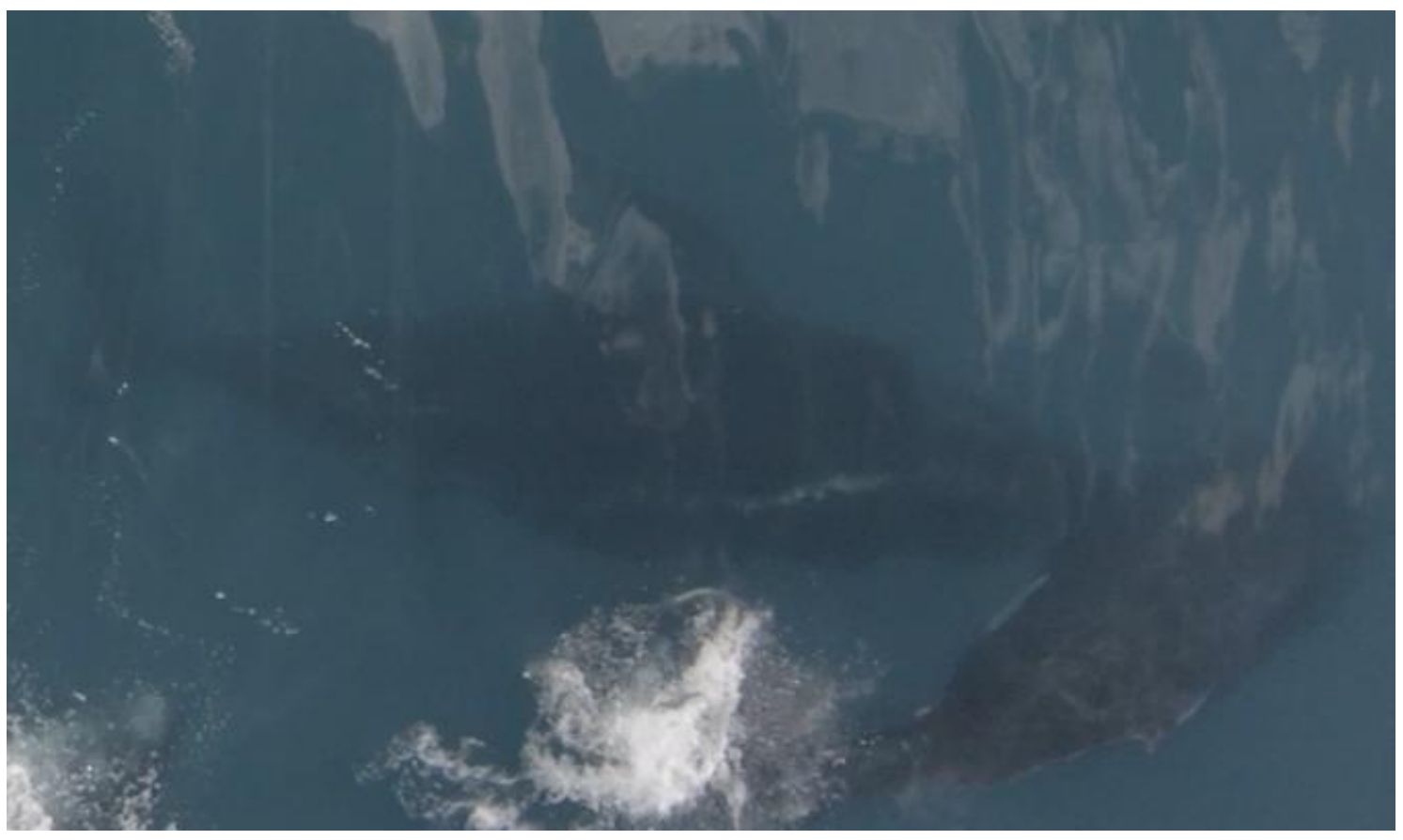

(B) 